\title{
PATTERNS OF REGIONAL AUTHORITY
}

\author{
Gary Marks \\ University of North Carolina at Chapel Hill \\ VU, Amsterdam \\ marks@unc.edu \\ Liesbet Hooghe \\ University of North Carolina at Chapel Hill \\ VU, Amsterdam \\ hooghe@unc.edu
}

Arjan Schakel

VU, Amsterdam

ah.schakel@fsw.vu.nl

Paper presented at the European Union Studies Association, Montreal, May 17-19, 2007 
Draft - please do not quote - comments welcome 
This paper summarizes some fundamental characteristics of regional authority in 42 democracies over the period 1950 to 2006 as evidenced in a new index. ${ }^{1}$

The index covers countries in the OECD, the EU, and former communist countries in Central and Eastern Europe. We assess regional authority for these countries on an annual basis from 1950, or since the introduction of democracy. So, for example, we evaluate Canada and Denmark from 1950, Portugal from 1976, Spain from 1978, and Hungary from $1990 .{ }^{2}$ An appendix to this paper summarizes the coding scheme and presents numerical estimates for all levels of regional governance aggregated to the country level.

\footnotetext{
${ }^{1}$ Arjan Schakel (2007) cross-validates the Regional Authority Index with prior measures, including Brancati (2006), Hooghe and Marks (2001), Lane and Ersson (1999), Lijphart (1999), Treisman (2002), and Woldendorp et al. (2000).

${ }^{2}$ We encompass democratic regimes for pragmatic reasons having to do with the quality and availability of data, and limitations in our expertise. We also hypothesize that formal rules - the phenomena we code-are more effective constraints on structures of power in democracies than in non-democracies. However, there is no a priori reason why our coding scheme could not be extended to regimes in which rulers violate the letter or the spirit of the law.

Communist regimes in Central and Eastern Europe are a case in point. Formal decentralization was undermined by the hegemony of the communist party. As James Hughes, Gwendolyn Sasse, and Claire Gordon observe: "Given that 'democratic centralism' was a common underlying organizational principle, the actual configuration of local government structures was relatively homogenous across Eastern Europe during the communist period. A vertical pyramidal system of 'elected soviets' (councils) extended down from the national structures at the centre to the regional, district and local levels.... These organizational structures provided a façade of popular legitimacy for the regimes while real power was highly centralized to communist party structures ... Regional administrations became essential outposts of central government for implementing the 'leading and guiding role' of the party in the country" (Hughes, Sasse, Gordon, 33-34, and 35.) It is no surprise, then, that, after the collapse of communism postcommunist governments throughout Central and Eastern Europe made it a priority to abolish regional government (O’Dwyer 2006: 219). In most countries, regionalization came only back on the political agenda after the consolidation of democracy.

Communist regimes provide a stark illustration of William Riker's insight that the degree of centralization in federal systems is linked to the degree of political party centralization (1964; Volden 2004). While Riker confined his analysis to federal systems, the logic applies rather well to decentralization and regionalization more generally. Communist democratic centralism was not equally successful in hollowing out formal territorial decentralization. It failed where the communist party was regionally divided or federalized, as in the Soviet Union, Yugoslavia and, after 1969, Czechoslovakia, and it encountered serious opposition where regional party bosses were able to water down central authorities, as in Poland until the mid-1970s, and in Russia.
} 
We follow Daniel Elazar (1991) in distinguishing between self-rule and shared rule. Self rule consists of a) the scope of policy for which a regional government is responsible (policy scope); b) the extent to which the region controls its financial envelope (tax authority); c) the extent to which a region is endowed with representative institutions (representation). We evaluate shared rule as the extent to which a region codetermines the authoritative decisions of the central government (role in central government). Our coding focuses on formal rules - formal norms, legislation, constitutional provisions - relating to these components. ${ }^{3}$

We caste a wide net in determining whether a level of government is regional. We include what the European Union designates at NUTS 1, NUTS 2, and NUTS 3 levels, that is, all levels of government that lie between local and national government. Of the 42 democracies in our dataset, 8 countries have no regional tier, 22 have one regional tier, and 12 countries have two. The country scores we refer to below are calculated by aggregating the scores for each regional level. Because there is no theoretical limit to the number of regional levels in a country, the Regional Authority Index (RAI) has no mathematical upper limit. Among the countries we evaluate, the highest scores are for Bosnia-Herzegovina (35.8 in 2006), Germany (33.0), and Belgium (30.5). The mean RAI in 2006 is 11.9. The spread is wide: the standard deviation is 10.7. Here we summarize some distinctive patterns that emerge from the data.

\footnotetext{
${ }^{3}$ The question of how formal rules constrain, or do not constrain, structures of party control, etc, is an empirical, not a definitional issue. We therefore do not include such phenomena in our index.
} 


\section{A pronounced, secular, uneven increase in regional authority}

Of the 42 countries that we evaluate, 20 saw an aggregate increase in regional authority over the period that we evaluate them, 18 saw no change, and four show a decline in regional authority. Let us take a closer look at the countries in these categories.

No country has become appreciably more centralized. Sweden has experienced the greatest decline in regional authority; its Regional Authority Index decreased from 11.5 to 10.0 from 1950 to 2006 as a result of the abolition of the upper chamber of the Riksdag in 1970 which was composed of regional (Län) representatives. SerbiaMontenegro drops just over one point on the Regional Authority Index because in 2003 it shifted from a federation to a confederation which all but dissolved the center, rendering power sharing with central government meaningless. The RAI for BosniaHerzegovina dropped a fraction in 2000 when the capital district Brčko was granted special autonomy. Brčko has somewhat less say in central government decision making than the two main regions, and this affects the country score. Finally, Canada dropped a fraction in 1999 because the partition of the Northern Territories into two territories slightly reduces the weight of regional governments in the country score.

Eighteen, or almost half of the countries that we examine, saw no change. The reasons for this are self-evident, and they point to fundamental constraints on regionalization. The first constraint is country size. A country with a small population has little space to squeeze an intermediate level of government between local authorities and the national government. On functional grounds, there may be little reason to pay the costs of having an additional level of government if local authorities 
cover populations up to, say 150,000 , and national government serves a national population below three million. The jurisdictional challenge for these countries lies in creating governance above the national state, not below it (Hooghe, Marks, de Vries 2006).

Eight of the 18 countries that experience no change in regional governance begin our time series with a Regional Authority Index of zero and finish in 2006 with zero. All have a population of 2.5 million or less, and the median population for the eight is 1.09 million. ${ }^{4}$

A second constraint on regionalization is that countries with very high levels of regionalization face a ceiling effect. Our measurement instrument does not impose a mathematical upper limit on regionalization because it is always logically possible to create and empower an additional level of regional governance. Large countries tend to have two levels of regional governance, not one, and it would be possible for them to create a third or fourth level. But this is a logical, rather than a practical, possibility. On average, the most regionalized countries, which have tend to have federal constitutions, inch up much more slowly than non-federal countries: on our index, average annual change (since 1950 or since democratization) is 0.14 for non-federal and 0.0015 for federal countries. Three federal countries (Germany, Switzerland, and the United States) experienced no change.

\footnotetext{
${ }^{4}$ Bulgaria, with a population of just under eight million, is the one larger country in our dataset whose regional tier in 2006 is merely deconcentrated administration (a score of 1).
} 
That leaves five countries which are not covered by the functional constraints of small population and the ceiling effect. These are Bulgaria $(\mathrm{RAI}=1.0)$, Japan $(8.0)$, the Netherlands (11.5), Portugal (2.5), and Turkey (5.0). The Netherlands was already quite decentralized in 1950 with stronger regional governance than all but three Western European countries, a historical residual of its confederal past. ${ }^{5}$ The remaining countries that saw no change are highly centralized given their population size. Bulgaria (with a population of 7.8 million) is the most centralized country in our dataset with a population greater than 2.5 million; Portugal (population 10.5 million) is the most centralized country in our dataset with a population greater than 7.8 million; Turkey (population 71.7 million) is the most centralized with a population greater than 10.5 million, and Japan (population 127.8 million) is the most centralized with a population greater than 71.7 million. Centralization and institutional stasis appear to be related. Each of these countries has a different story. ${ }^{6}$ However, in this essay we must try to contain our eagerness to chase after individual cases, but instead restrict ourselves to the general pattern.

What we can say is that it is easier to identify the characteristics of countries that did not regionalize than to identify the characteristics of countries that did regionalize. This is actually a revealing statement, for it suggests that the causes of regionalization are diverse. Regionalization has taken place in small countries and large countries

\footnotetext{
${ }^{5}$ The Netherlands is an interesting case for examining Riker's hypothesis concerning the interplay between party centralization and constitutional rules. While the provinces have extensive formal power over central government policy by means of their presence in the upper chamber, in reality upper chamber representatives sit and vote according to party affiliation rather than provincial loyalty. ${ }^{6}$ Perhaps a common thread is an ideological attachment to national unity that reaches across the political spectrum to parties of the left as on the right.
} 
(measured by population and territorial size), ethnically diverse societies and ethnically homogenous societies, countries that were centralized in 1950 and countries that were decentralized in 1950, established democracies and recent democracies.

This pattern is consistent with a postfunctionalist account of multilevel governance that assumes that the provision of governance is subject to functional pressures, but that the extent to which these pressures lead to reform depends on their distributional effects and their identity effects (Hooghe and Marks 2007). Functional pressures arise because some collective problems (such as town planning; fire protection, nursery schooling and kindergarten) are best handled at a population scale of tens of thousands, some (such as vocational and technical education; secondary education; and hospitals) are best handled at a scale of hundred of thousands, some (such as tourism promotion; environmental protection; and transport infrastructure) are best handled at a scale of millions, while yet other problems demand jurisdictions that are vastly larger. ${ }^{7}$ This functional approach presumes considerable dynamism, not stasis, if the policy portfolio of a polity changes. If conventional war-making dominates policy, as it did in the first half of the twentieth century, then one would expect functional pressure for concentrating decision making at the most centralized level available, i.e. the central state. War-making and extracting resources necessary for war was instrumental in the development of national systems of education, national systems of taxation, conscription, national ownership or control of mineral extraction, transport, and munitions. In the years immediately following World War II, central states were

7 This list is derived from our (as yet unpublished) expert survey of efficient jurisdictional design. 
also called upon to distribute extreme scarcity and to mobilize resources, human and financial, to begin rebuilding battered economies.

The period since 1950 has seen unparalleled diversification in the policy portfolio of national states to welfare, environmental, educational, infrastructural, and microeconomic policies. Unlike conventional war-making, these policies do not press authority towards the central state. The functional logic of regional governance requires simply that the policy portfolio of national states has come to include policies that are most efficiently delivered at diverse jurisdictional scales, including a regional level between the local and national.

Countries that did not experience regionalization in the post-1950 period are, therefore, likely to be those that were not subject to this functional pressure-very small countries or countries that already had strong regional governments. Predicting the positive side of the equation is more difficult because one cannot assume that functional pressure leads to jurisdictional reform. This is not just because institutions are sticky, and correspondingly, that institutional reform is inherently difficult to point-predict. More importantly, political choice intervenes between functional pressures and institutional outcomes. The level of authoritative decision making has consequences for the distribution of power, for the distribution of income, and for self-governance. As we look further into the data we have gathered, the causal force of these intervening political factors will become apparent.

Figure 1 summarizes regionalization in the 21 democracies which we measure continuously from 1950 to 2006. The ratchet-like character of the process is evident. As 
noted above, we are evidently dealing with a process that is nearly uni-directional and one that has taken place over an extended period of time. But there is another salient feature: a sharp discontinuity in the rate of change around 1970. Before 1970, the series is almost flat; after 1970, there is a sharp, sustained, upward trend.

[Figure 1 about here]

This discontinuity coincides with a cultural shock that swept across the globe in the late 1960s, and which in the West took the form of youth rebellion and new forms of self-expression that questioned or, more usually, confronted, conventional norms.

Norms that were taken for granted -including materialism, cultural progress, and short hair-were explicitly challenged as were political norms, including deference to political leaders and centralized decision making. In 1973, E. F. Schumacher wrote a book entitled "Small is Beautiful" which fiercely questioned the virtues of a materialist culture based on ever larger organizations that were out of touch with human need. Preferences for greater self-determination and popular democracy were most likely to mobilize demands for change in centralized democracies, particularly where there were territorially concentrated ethnic minorities. ${ }^{8}$

The first moves in the early 1970s relaxed centralization in formerly highly centralized states - creating regions and communities in Belgium (1970); direct elections for Amter in Denmark (1970), a level of regional governance in France (1972); longpromised regionalization (including directly elected regional assemblies) in Italy (1972);

\footnotetext{
8 We do not have a very good measure for territorially concentrated ethnic minorities, but two proxies ethnic fragmentation (the probability that two randomly selected individuals belong to a different ethnic group) and linguistic fragmentation (based on linguistic proximities) - are weakly associated with the level of regional authority (controlling for population size): 0.34 and 0.33 respectively.
} 
regional councils in New Zealand (1974), directly elected Fylke in Norway (1975) and creation of comunidades autonomas in Spain (1978). These were followed by reforms that put guts in newly created territorial tiers - regions and communities in Belgium (1980), directly elected regional councils in New Zealand (1989) - or that deepened existing regional tiers - constitutional power sharing in Austria (1984), broader competencies for Italian $(1976,1989)$ and Spanish (1979-1994) regions, and competencies and direct elections for French regions $(1982,1986)$. This was also an era in which special autonomy was granted on an ad hoc basis to anomalous, often outlying, territories such as Greenland (from Denmark in 1979), the Northern Territory (Australia 1974), Corsica (1982), Canberra (Australia 1989), and Scotland and Wales (United Kingdom 1999).

\section{The composition of regionalization}

Figure 1 charts regionalization and its four main components for 21 democracies that we evaluate continuously since 1950 . The pattern is revealing.

The greatest change has been in the institutionalization of directly elected regional assemblies. Elected institutions at the regional level have always been a facet of federal polities, but the idea has spread. The mean score on our 8-point scale is 2.3 for 1950; rising to 4.0 in $2006 .{ }^{9}$ Across the entire dataset of 42 countries, 23 countries had directly elected regional assemblies in 1950 or when they became democratic. In 2006, 33 countries had adopted the principle.

\footnotetext{
${ }^{9}$ The scale has a ceiling greater than eight because some countries have two regional levels.
} 
Interestingly, this is a reform that cannot be laid at the door of functional pressures. The provision of elected assemblies appears more in line with the cultural changes of the post-sixties era than with an efficiency argument based on the territorial scope of externalities and economies of scale.

The second major change has been in the policy portfolio of regional governments. In 1950, the mean score was 4.3, rising to 5.8 in 2006. Again, the development is uneven: ten countries saw an increase in regional competencies; eleven (including all but one federal country, Australia) saw no change. The greatest increases were in Belgium (+8), Italy (+6.4), Greece $(+5)$, and France (+4), and in several special autonomous regions: Greenland (+8), Scotland and Northern Ireland (+7), Wales (+4), and the Greater London Authority (+4).

Regional power over taxation has grown, but on our 8-point scale the absolute change has been a modest increase from 2.2 in 1950 to 3.0 in $2006 .{ }^{10}$ The role of regions in central government decision making has risen only slightly, from 2.1 in 1950 to 2.4 in 2006. 11

These components of regional authority appear to be quite tightly coupled. Countries that saw an increase in one component tended to see an increase across the board. A principal components factor analysis of the four change variables (for 2006

\footnotetext{
10 Among the 21 established democracies, one finds the greatest tax authority in 2006 in five federal countries: Australia, Canada, Switzerland, the United States (8) and Belgium (6); Germany, where extensive power sharing offsets relatively weak tax autonomy for the Länder, has a score of 5 on our index. Among the later democracies, only Bosnia \& Herzegovina (10.6), Serbia \& Montenegro (8.9), and Spain (6) join this group.

11 The greatest increases occurred in Belgium (+4), Austria (+2), and Australia (+1.1); in Sweden, power sharing declined by 3.5 on an 8-point scale triggered by the abolition of the upper chamber.
} 
minus 1950 for 21 democracies) produces a single factor explaining 66.7 percent of the variance. The Cronbach's alpha is 0.83 .12

\section{$\underline{\text { Five generalizations }}$}

We suggest the following five generalizations about the level of regional authority and the process of regionalization:

- A ceiling effect, in which the greater the level of regional authority in a country, the smaller its increase. We expect the effect to be an increasing, not linear, function of the level of regional authority. It can be modeled as the inverse of the square of the regional authority $(\mathrm{R})$.

$$
\uparrow R=\frac{1}{R^{2}}
$$

To evaluate the validity of this hypothesis (Richard Feynman [1965] would call it a "guess") requires multivariate analysis, a project beyond this essay. Here we must be content to present a figure which provides some prima facie evidence for a negative association between the level of regional authority and its rate of increase. ${ }^{13}$

\footnotetext{
12 The Cronbach's alpha for absolute levels of the four components across 42 countries in 2006 is 0.89 .

${ }^{13}$ This formulation of the ceiling effect applies to our current era of emergent multilevel governance, but there is nothing intrinsic about rising levels of regionalization (or rising levels of Europeanization). The logic of our argument is that multilevel governance could be reversed because the policy portfolio changes (compressing competencies to a single authoritative level, e.g., in response to war); for distributional reasons (for example, when a dictator identifies his own interest with that of compressing
} 
[Figure 2 about here]

An S-curve effect, where the association of country size (measured in population and in territory) on regional authority depends on the absolute size of a country. Across countries below a certain size, there is little functional benefit in regional authority. At some point (between two and three million population) the benefits of regional authority emerge, and increase rapidly until the population reaches between twenty and thirty million, at which point the benefits of regionalization in relation to population level off. No country in our dataset with a population of less than two million has regional governance. No country with a population of more than 20 million lacks regional governance.

- A diversity effect, in which countries with territorially distinct ethno-cultural minorities have higher levels of regional authority than more than homogenous countries. The diversity effect arises because individuals have preferences over policy and preferences over self-rule. The policy argument hypothesizes that

authority in his own hands); or on account of the mobilization of an exclusive identity (e.g. nationalism). Such scenarios entice us to theorize the decline of regional authority as well as its rise, and so we hypothesize a more general association:

$$
\Delta R=\frac{1}{R^{2}}
$$

The rationale for this is that regional authority in federal polities (which tend to have high levels of regional authority) is more difficult to reverse (i.e. stickier) than regional authority in non-federal systems. However, an evaluation of the validity of this hypothesis will have to wait for the current era of rising multilevel governance to end. 
individuals with different ethno-cultural traditions desire heterogeneous mixes of public goods, such as education, welfare, and economic policy (Alesina and Spolaore 2001). The self-rule argument hypothesizes that individuals sharing ethnocultural norms desire some self-rule, that is, a capacity to project institutionalized power into the future (Keating 1997; Loughlin 2001).

Figure 3 plots the level of regional authority against the natural logarithm of population for 2006 for the 42 countries in our dataset. As we expect, more populous countries are more regionalized. What is of interest here, however, is that countries that have unusually high regional scores tend to be those with ethnic minorities, which we identify with dark circles in the figure.

[Figure 3]

- A democracy effect, in which democracies have a higher level of regional authority than non-democracies. As noted above, this assertion is rooted in a strong prior: democracies allocate authority not in terms of a ruler's ability to amass power in his own hands and eliminate that of challengers (or simply eliminate challengers), but in terms of winning votes in competitive elections. Monocracy suffocates multilevel governance, democracy is agnostic.

We cannot evaluate the validity of this hypothesis in a dataset where the case selection is heavily biased to democratic polities, but the evidence that we have about change is in line with this expectation. The logical implication of the democracy effect is that a country that shifts from autocracy to democracy will be newly subject 
to the pressures discussed above. Figure 4 charts average increases in regional authority in three groups of countries, and reveals that the post-communist regimes of Eastern Europe have high rates of change.

[Figure 4]

- A trade insulation effect, in which regionalization is stimulated when it has no effect on trade and hindered when it disrupts trade. If reform to create regional political autonomy does not harm a region's participation in the international division of labor, then we can speak of regional authority as a decomposable good. A region can have its cake and eat it, so to speak. If economic autarky is part of the package, then the economic cost of regionalization will be significant, and perhaps prohibitive.

So when might political autonomy be detachable from economic autarky? Most obviously, when rules concerning trade and economic exchange are already detached from the national state, i.e. when there is an overarching set of international rules that will be insulated from authoritative reform within a member state. This is not the only circumstance in which regional authority is a decomposable good, but it is one that we see very clearly in figure 4 , above. 


\section{Conclusion}

Regional governance appears to have an explicable set of logics that derive from its functional and political sources. In this paper we set some of these out with the help of a measure of regional authority covering 42 democracies since 1950.

The structure of jurisdictional design is distinctive in two respects. First, the direction of change appears to be highly uniform. Where we see jurisdictional change in the last 56 years it is almost exclusively in one direction. We detect 60 cases of jurisdictional reform of which 51 empowered regions. The average increase in regionalization as measured on the index is 2.95 . The average regional decline across the nine contrary cases is $-0.94 .{ }^{14}$ So we detect five times as many instances of regionalization as anti-regionalization, and their mean individual value is three times as great.

We suspect that homogeneity of change is not unique to the post World War II period. The previous era, which may have lasted for considerably more than a century, was characterized by similar uniformity in the direction of change, but with the opposite sign. An era of centralization has been followed by an era of regionalization. We have suggested some reasons why this might have happened, but we have not mentioned several plausible alternative explanations, including international diffusion.

Second, there is very wide variation across countries in the level of regional authority (and by implication, in the level of central state authority). Seven of the 42

\footnotetext{
14 Three of these are in the UK, and arise from the changing status of Northern Ireland and the reorganization of local authorities in Scotland and Wales prior to devolution.
} 
countries we examine had no regional level of government, even after more than half a century of regionalization. Twelve countries have regions that exert considerable authority, scoring more than 20 on the Regional Authority Index. The standard deviation in the RAI, at 10.7 is almost as great as its mean level, 11.9. We suspect that this variation is also historically robust. Although many polities in the nineteenth century and first half of the twentieth century became more centralized, federal polities continued to co-exist with highly centralized polities.

The jurisdictional architecture of polities is in equal parts puzzling and fascinating. The measure we have created helps to reveal not simply the course of jurisdictional reform, but also some basic questions that remain unanswered. 
Figure 1:

Evolution of Regional Authority in Established Democracies (1950-2006)
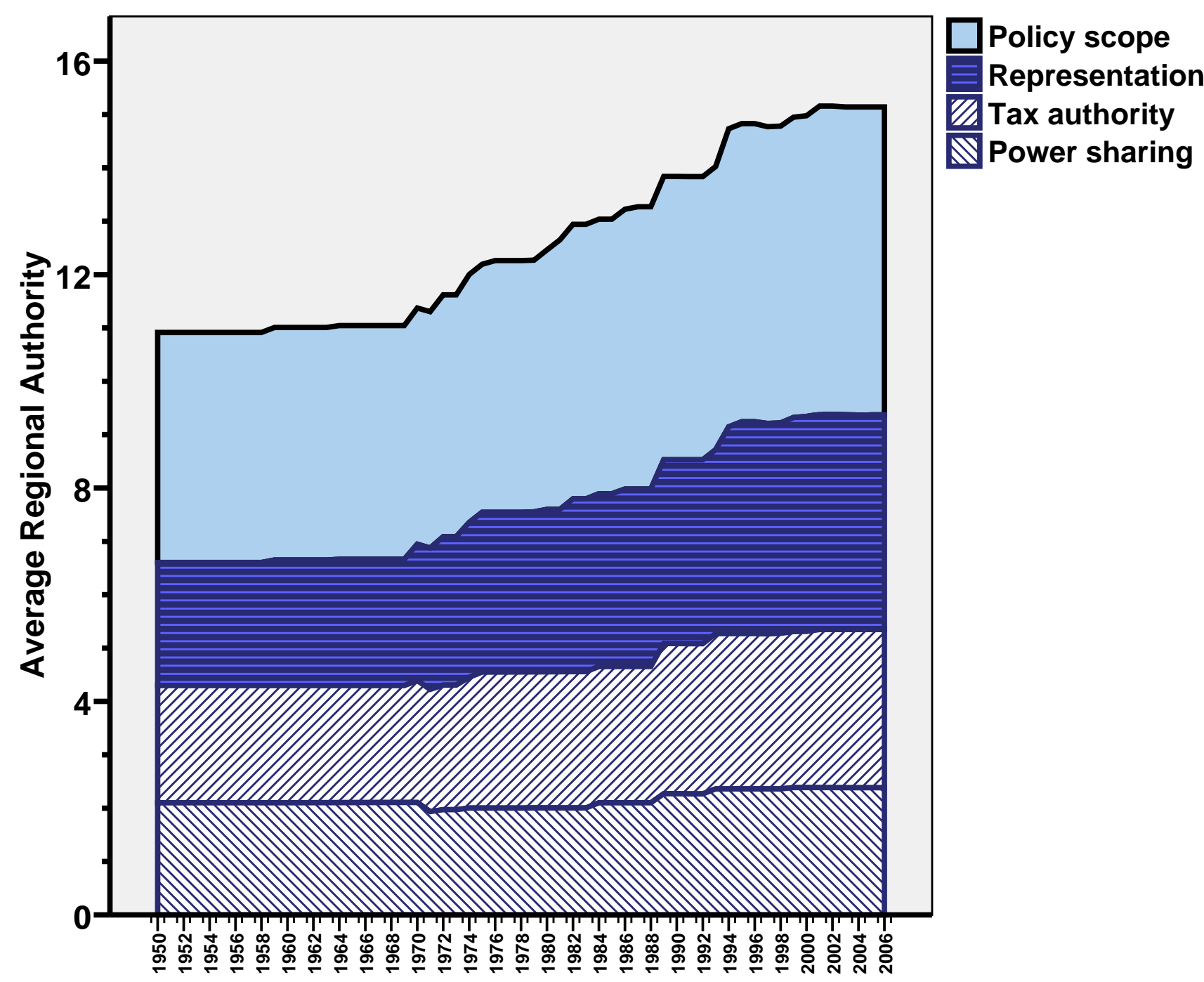

Note: Yearly average for 21 democracies since 1950.

Policy scope $=$ breadth of regional policy responsibility (0-8);

Representation $=$ existence and role of regional legislature (0-4);

Tax authority = extent to which the region controls its revenue $(0-8)$;

Power sharing $=$ extent to which the region affects central government decisions (0-8).

Full coding described in Appendix. 
Figure 2:

The Ceiling Effect

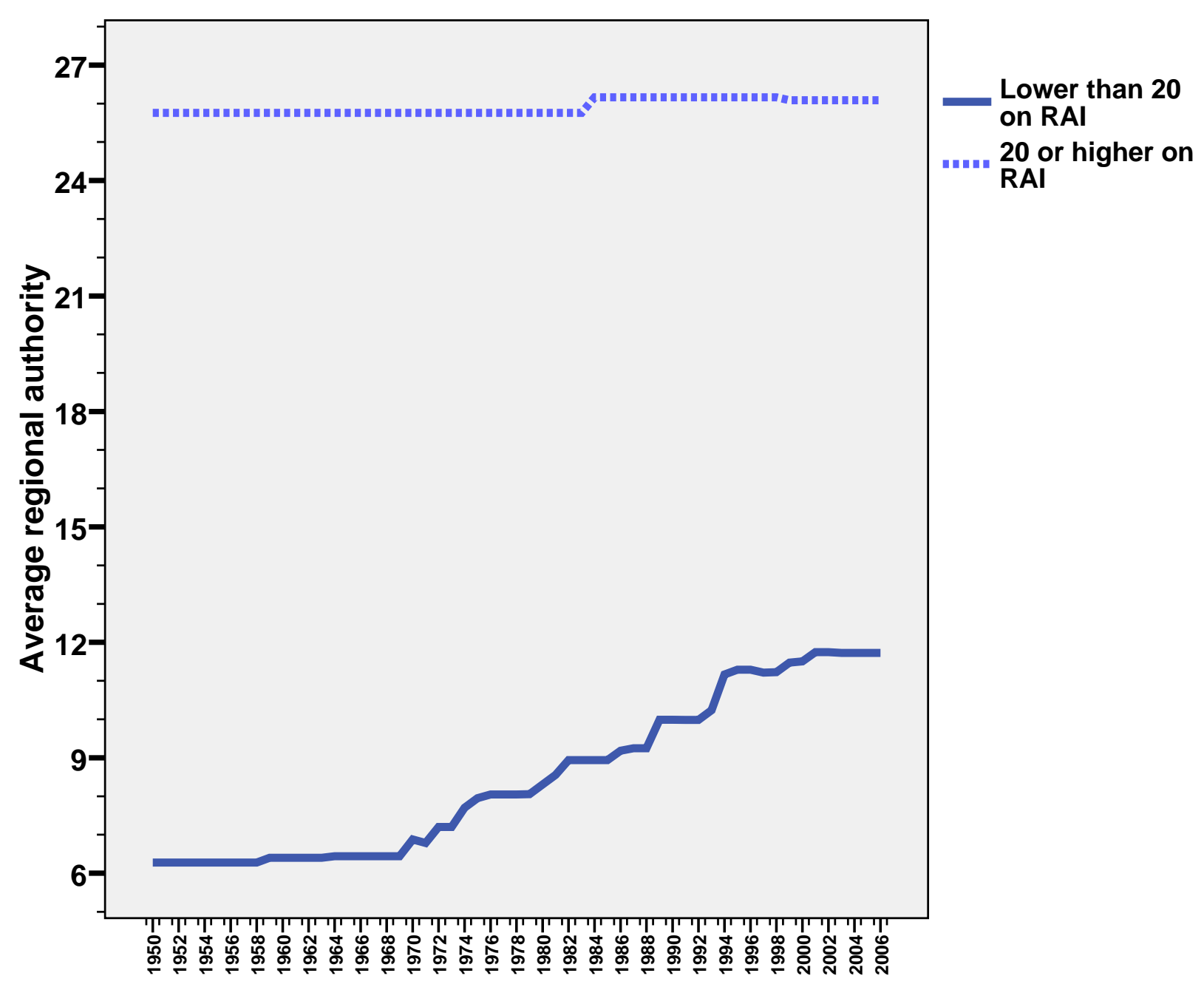

Note: 21 democracies continuously evaluated 1950-2006. The RAI $\geq 20$ category consists of Austria, Canada, Germany, Switzerland, and the United States. 
Figure 3:

\section{Population, Ethnicity, and Regional Authority}

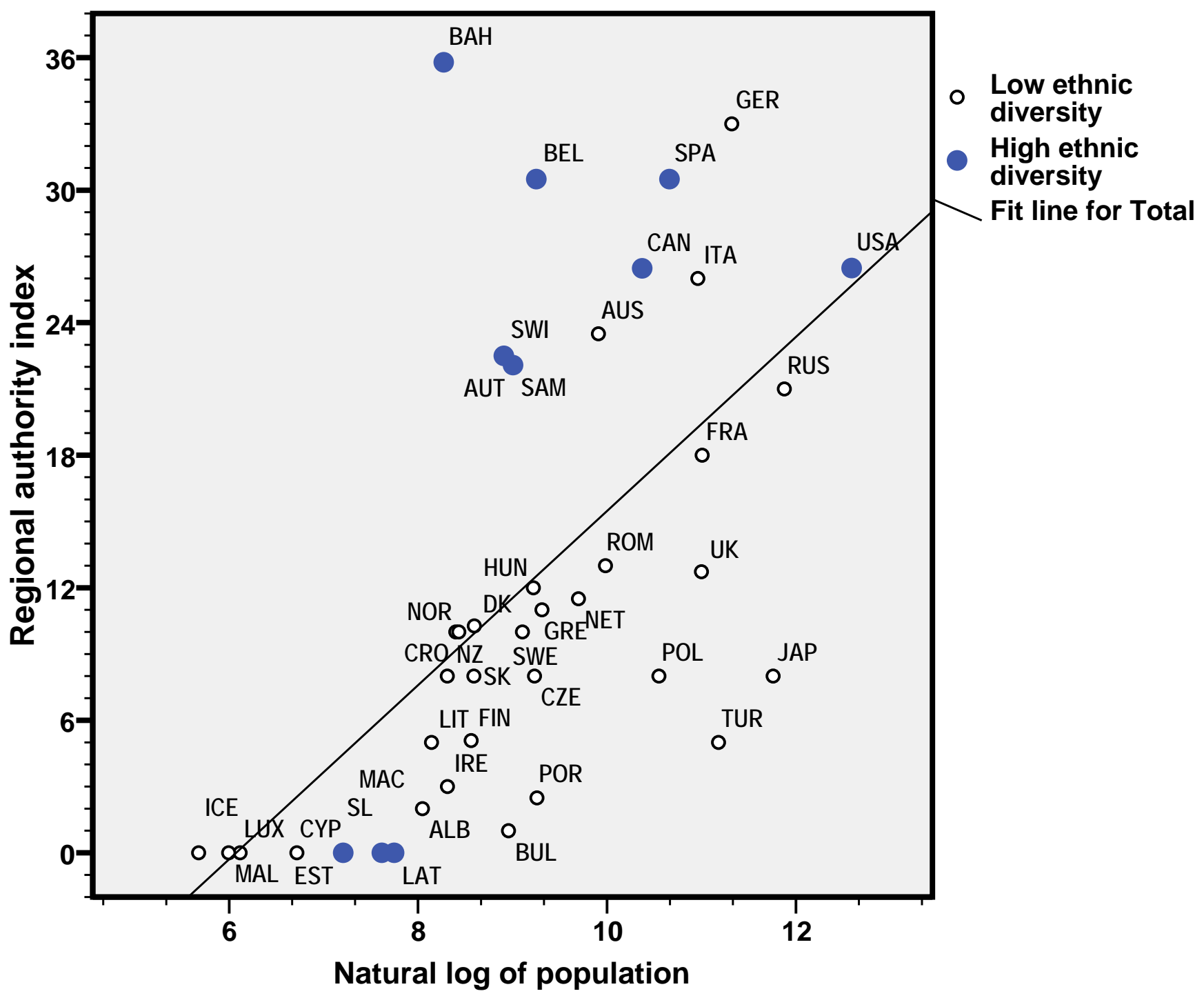

Note: 42 countries.

Population: Natural $\log$ of $6=$ population of 0.403 million; $8=2.98$ million; $10=22.0$ million; 12 $=162.8$ million; $13=442.4$ million.

Ethnicity: ethnic fragmentation index which represents the probability that two randomly selected individuals belong to a different ethnic group (xxx). We dichotomize this variable at a natural breakpoint in our dataset, where $1=$ index value of 0.4 or greater. 
Figure 4:

Annual Change in Regional Authority by Decade

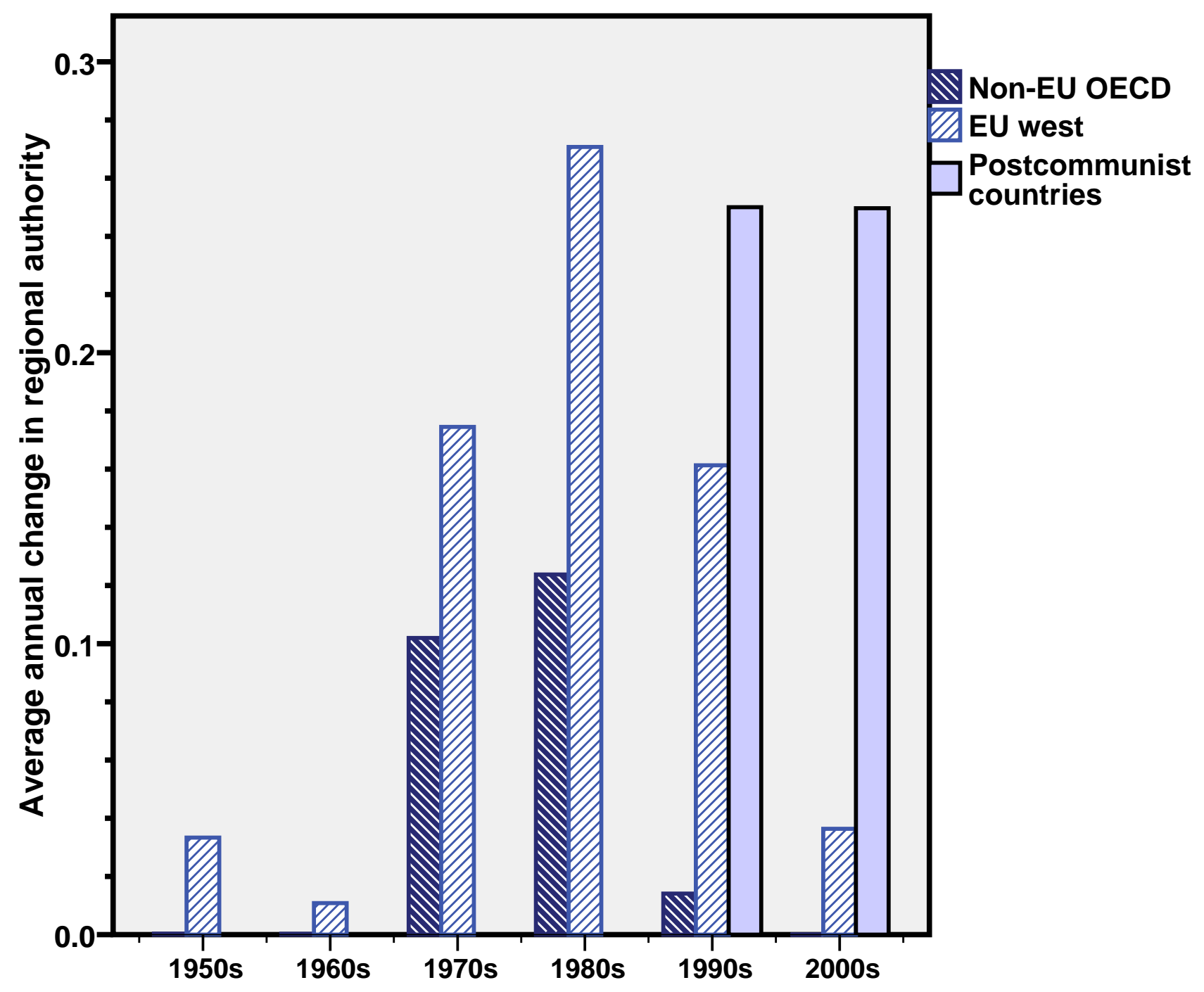

Note: Annual change in Regional Authority Index for 35 democracies, 1950-2006, averaged by decade. 


\section{Appendix: An Index of Regional Authority}

The region is a rubbery concept stretching above and below the national state. Our focus here is on subnational regions, but there is no generally accepted definition that we can take on board that will readily produce a set of homogenous units for crossnational comparison. Our first and immediate task then is to conceptualize the region in a way that meets, as far as possible, normal linguistic usage while providing the researcher with a meaningful and unambiguous unit of analysis.

Our basic conceptual decisions are as follows:

First, a region refers to a given territory having by single, continuous, and nonintersecting boundary with respect to the boundaries of other regions.

Second, a political region, the object of our analysis, is distinguished by a set of institutions responsible for binding decision making.

Third, regions are located between local governments and national governments.

For our purposes, then, a region is a coherent territorial entity situated between local and national government which possesses institutions that engage in binding decision making.

This definition is intentionally minimal. Our purpose is to define a particular set of objects while leaving unspecified their salient political characteristics for empirical evaluation. These include the extent to which a region exercises authority. If the region merely reflects the will of the central government, we describe regional governance as deconcentrated; to the extent that a region exerts independent influence over binding decisions, we describe it as autonomous.

Then there is the vexed issue of the possible existence of more than one level of regional governance in a country. Local governments and national governments define extremes within which there may be plural intermediate levels. How do we determine which level is the regional? In previous work, we selected the most authoritative level as the region that we measured. But this is problematic, for it is unable to account for countries where there are two levels of autonomous regional governance. Here we take a comprehensive approach. We measure the authority exercised by all intermediate levels of governance specified by the NUTS (Nomenclature des Unités Territoriales Statistiques) classification of the European Union. ${ }^{15}$ This is more demanding, but it has the virtue of providing scores for regional governance at all appropriate levels. When using this index, the reader may choose to examine the disaggregated scores we provide for each regional level or aggregate scores for each country.

We estimate regional authority across 42 countries, including all 27 countries in the European Union, the Balkan countries, Norway, Switzerland, Iceland, Russia, Turkey, and several non-European countries - Australia, Canada, Japan, New Zealand, and the United States. We assess regional authority for each of these countries

\footnotetext{
15 Regional government encompasses all regional governments that meet the NUTS 1, NUTS 2 or NUTS 3 criterion. This classification scheme is used in most European countries, including several non-EU countries (e.g. Norway and Switzerland). For countries that do not use the NUTS classification, we apply the population size criteria which underlie the NUTS categorization.
} 
continuously in annual increments for the period 1950 or since the introduction of democracy to 2006.

The index set out here builds on the Regional Governance Index in Hooghe and Marks (2001), but there are several differences:

- The unit of analysis for the prior index was the country; here it is the region.

- The prior index evaluated only the most authoritative regional level; here we evaluate all regional levels that meet the NUTS 1, 2, or 3 criteria.

- The prior index summarized scores by decade; here we provide scores on an annual basis as regional authority changes.

- We now extend the index to 2006.

- The prior index covered 14 EU countries; here we extend this to an additional 28 countries in and beyond Europe.

- Finally, the new index introduces a new dimension, regional tax authority, and significantly revises the other three dimensions.

We operationalize authority as a multi-dimensional concept. To begin with, it varies with respect to its breadth and its depth. Breadth refers to the scope of policy for which a region government is responsible. Depth refers to authority exercised over policy decisions. Authoritative depth is compounded of a) the extent to which the region controls its financial envelope; $b$ ) the extent to which a region exerts authority independently of the central government; and c) the extent to which a region codetermines the authoritative decisions of the central government.

We summarize the constituents of regional authority as follows:

- Policy scope: How broad is the policy responsibility of regional institutions?

- Tax authority: To what extent does the region control its revenue

- Representation: Does the region have an independent, elected, legislature?

- Role of regions in central government: To what extent can the region affect central government decisions?

These elements pertain to formal authority. They are explicitly mandated in legislation and in national constitutions. This enhances the reliability of our coding. But there is a more compelling reason for distinguishing formal authority from informal norms. We are interested in how formal rules are empirically related to informal sources of power arising from ideology, strategic bargaining, party (de)centralization, and corruption. We therefore need to evaluate formal rules independently from these factors.

Below we detail our coding for each of these dimensions.

\section{Policy Scope}

Policy scope taps the formal scope of regional governance over substantive policy making. Here, as elsewhere in our index, sequential categories are scored on a base- 2 
logarithm. This may be unfamiliar, but it has a logic that is perfectly adapted to our purpose. It is simple, intuitive, and substantively appropriate. The underlying idea is that the intervals in our scoring increase with the authority of a region. That is to say, the absolute difference in the authority exercised by a weak and a very weak region is far smaller than that between a strong and a very strong region. As we move along our scale, absolute differences increase while the ratio of one score to the next remains constant.

The categories set out below are cumulative. That is to say, a region with a given score is presumed to meet the criteria that produce a lower score. So all regions coded one or more have a functioning regional administration; all regions coded two or more exercise significant authority over economic policy, cultural-educational policy, and/or welfare state policy; and so forth.

- 1: a functioning general-purpose regional administration;

- 2: exercises significant authority in one of the following areas: economic policy, cultural-educational policy, welfare state policy;

- 4: exercises significant authority in at least two of the following areas: economic policy, cultural-educational policy, welfare state policy;

- 8: exercises significant authority in at least two of the following areas: economic policy, cultural-educational policy, welfare state policy; and has coercive or constitutive power over two or more of the following: local government, police, regional political institutions (e.g. regional administrative organization, the budget process, regional elections), residual powers (i.e. powers not constitutionally specified).

\section{Tax Authority}

The capacity to collect and spend money is an vital component of regional authority. One commonly-used measure is the amount of money a region spends. The problem with this is that deconcentrated regions (i.e. regions with little or no autonomy from central government) are, in some cases, big spenders. The approach we take here is to assess the extent to which a region has discretion to tax. We revise [explain howxxx] the criteria of the Organization of Economic Cooperation and Development (Tax Policy Studies, 1999) to measure the degree of formal control a region has over its sources of revenue. As with policy scope we apply a logistic scale for all positive integers to represent the cumulative nature of the scale and the increasing intervals between our evaluation points.

- 0 : revenue from any tax is unilaterally determined by the central government and/or the central government sets base and rate of regional taxes;

- 1: the region sets the rate of regional taxes, but this does not encompass income, corporate, value added, or sales taxes; 
- 2: the region sets the base and rate of regional taxes, but this does not encompass income, corporate, value added, or sales taxes; or the region sets the rate of one or more of income, corporate, value added, or sales tax;

- 4: the region sets the base for all regional taxes; or it has a veto over the central/regional distribution of revenue from income, corporate, value added, or sales taxes;

- 8: the region sets the base and rate of one or more of income, corporate, value added, or sales tax.

\section{Representative Institutions}

Regional executives may be accountable to the central state or to regional assemblies. Even when representative regional institutions cannot dismiss regional executives, such institutions increase the legitimacy, and therefore, the authority, of regional governments. Some regions have directly elected regional assemblies; others have indirectly elected regional assemblies; and yet others (the majority of regions in our dataset) have no regional assemblies. Our scoring assesses a) whether the executive is regionally elected or appointed by the central government, and $b$ ) whether the regional legislature is popularly elected, indirectly elected, or appointed by the central government. Our scoring here is non-cumulative, and it has a maximum score of four (i.e. half that of policy scope or tax power).

- 0: no regional legislative assembly;

- 1: regional legislative assembly is popularly elected or indirectly elected (i.e. composed of elected local government representatives), but the head of the regional executive is a national appointee;

- 2: regional assembly is indirectly elected (i.e. composed of elected local government representatives), and the executive head is elected by the assembly or is popularly elected;

- 4: regional assembly is popularly elected, and the executive head is elected by the assembly or is popularly elected.

\section{Role in Central Government}

Regions may exercise authority on account of their role in national decision making. We distinguish three avenues. First, regions may participate directly in making national laws. This requires that they are represented in the national legislature, usually in an upper chamber that is (partially or wholly) devoted to subnational interests. Second, regional governments may share executive responsibility with the national government for implementing policy in the region and in the country as a whole. Finally, and most importantly, regions may play a role in decisions about which level of government does what, how, and with what resources. Regions may, in short, co-determine the allocation of authority in a polity. The first and second avenues of power-sharing concern the role that regions play in national decision making and we score each a maximum of two 
points; the final avenue concerns the extent to which regions write the rules of the game, and we score this up to four points.

Regional authority in power sharing varies considerably. Mere representation does not imply decisional power. By the same token, regional executives may convene regularly with the central government in intergovernmental conferences, but such meetings may not bind the central government. We therefore need to distinguish between the share of regional representation in a legislature (often an upper chamber) or executive, and the power of these bodies.

\section{Constitutional power sharing}

- 1: the upper house is popularly elected and a majority or supermajority of representatives must approve constitutional change;

- 2: regional governments/parliaments - or their representatives in the upper house-must be consulted on constitutional change and have the power to postpone decision, introduce amendments, increase the decision hurdle in the lower chamber, require a second vote in the lower chamber, or require approval by a popular referendum; or: a majority of regional governments / parliaments - or their representatives in the upper housemust approve constitutional change;

- 4: a supermajority of regional governments/parliaments - or their representatives in the upper house-must approve constitutional change.

\section{Legislative power sharing}

We score $\mathbf{0 . 5}$ point for each of the following characteristics:

- Regions are the unit of representation in the upper chamber, i.e. the distribution of representation in the legislature is determined by regional weights, rather than "one citizen, one vote" in the country as a whole.

- Regional governments/legislatures designate representatives to represent their interests in the upper chamber.

- Regions at a given level have a majority of representation in the upper chamber.

- The upper chamber has wide-ranging authority, that is to say, it has extensive legislative power, wields a veto on some important issues, or has the power to increase the decision hurdle (e.g. to a two-thirds majority in another legislature).

\section{Executive power sharing}

- 1: routine of intergovernmental meetings between central government and regional governments without authority to reach binding decisions;

- 2: routine of intergovernmental meetings between central government and regional governments with authority to reach binding decisions. 


\section{Asymmetrical and Special Autonomous Regions}

We apply the same coding scheme for asymmetrical and special autonomous regions, though we make minor adjustments for the latter to take into account the special character of these regions. We speak of an asymmetrical arrangement when a region falls under a country-wide constitutional structure, but enjoys more (or sometimes less) extensive powers in terms of policy scope, representation, tax power or power sharing than other regions relative to the central government. Asymmetry is frequently proposed as a solution to the dissatisfactions that arise when a perception of significant ethnic, linguistic or cultural differences set a region apart from others. Asymmetrical arrangements may be temporary, as e.g. for the historical regions in Spain, or indefinite, as for example, for the territories in Canada or Australia. Special autonomous regions differ from asymmetrical or typical regions in that their statute is sui generis: they are exempt from the country-wide jurisdictional framework, and they receive special treatment in the constitution or equivalent formal statutory laws. ${ }^{16}$ So while asymmetrical regions could be described as "+/- typical regions," special autonomous regions are more aptly conceived as opt-outs.

The peculiar situation of special autonomous regions makes it more difficult for them to claim shared rule. If there is an upper chamber that reflects regional interests, special autonomous regions are always in the minority; if there are intergovernmental meetings, they usually influence only the particular effects of a policy in the autonomous region; if the autonomous region has constitutional power, it is usually limited to its bilateral relation with the host country - not the constitutional architecture of the country as a whole. ${ }^{17}$ Shared rule, then, tends to be confined to shaping central policy with respect to the territory - rather than shaping policy for the country as a whole. The flipside is that special autonomous regions, unlike other regions, usually have considerable input in - sometimes ultimate authority over-central government policy in their territory.

\footnotetext{
${ }^{16}$ Most special autonomous regions would normally classify as a Local Authority Units (LAU) if one were to apply the formal population criteria of the NUTS categorization. But in reality, special autonomous regions usually fall under one of the upper NUTS categories. The Åland islands (Finland), for example, fall under the EU's NUTS 1. Ceuta and Mellila (Spain) have been NUTS 3 since Spain became a member of the EU, and were upgraded to NUTS 2 in 1995 when they became full-fledged communidades. Corse (France) and Açores and Madeira (Portugal) are NUTS 2 even though their population size would warrant a NUTS 3 classification.

17 Our notion of special autonomous region combines three special arrangements which Daniel Elazar defines as associated state, federacy, and home-rule territory - in order of declining autonomy. An associated state is an asymmetrical arrangement whereby a larger power and smaller polity are linked asymmetrically in a federal relationship in which the latter has substantial autonomy and in return has a minimal role in the governance of the larger power; like a confederation, it can be dissolved unilaterally by either of the parties under pre-arranged terms. A federacy is similar to an associated state in terms of internal autonomy, except that, like in a federation, the relationship between them can be dissolved only by mutual agreement. Finally, home rule territories have significant powers of self-government, but unlike the federacy and associated state relationships, the central government of the state typically plays an active role in some areas of the home-rule territory's internal government, such as internal security, judicial matters, and economic and monetary matters (Elazar 1997: 398).
} 
We apply the same criteria for measuring the authority of asymmetrical regions as we do for other regions. For special autonomous regions, we use the same criteria for policy scope, representation and tax power, and we tailor the criteria of power sharing to their special situation in the following way:

\section{Constitutional power sharing (0-4):}

- 1: the regional government/legislature is consulted by the central government/ parliament on constitutional amendments that affect its position in the national state, but the consultation is not binding;

- 2: the regional government/legislature and central government/ parliament co-decide constitutional amendments that affect the region's position in the national state: both have veto power;

- 4: the regional government/legislature can unilaterally accept or reject constitutional amendments that affect the region's position in the national state.

\section{Legislative power sharing (0-2):}

We score each of the following characteristics in the following way:

- 0.5: the region is the unit of representation in the upper and lower chambers;

- 0.5 : the regional government/legislature designates representatives in the upper chamber;

- 0.5: the regional government/ parliament/ regional representation in the upper chamber is consulted on national legislation affecting the region;

- 0.5: the regional government/ parliament/ regional representation in the upper chamber has veto power over national legislation affecting the region.

\section{Executive power sharing (0-2):}

- 1: routine of intergovernmental meetings between central government and the regional government for consultation on executive matters affecting the region; no binding authority;

- 2: routine of intergovernmental meetings between central government and the regional government for consultation and arbitration on executive matters affecting the region; binding authority.

\section{Country Scores}

We obtain country scores by aggregating the scores of constituent regions. Where a country has a special autonomous region, we weigh the score of the region by its population. 
Appendix: Regional Authority Index in 42 Democracies, 1950-2006, Country Scores

\begin{tabular}{|c|c|c|c|c|c|c|c|c|c|c|}
\hline Country & Year & Self-rule & $\begin{array}{l}\text { Policy } \\
\text { scope }\end{array}$ & $\begin{array}{c}\text { Tax } \\
\text { power }\end{array}$ & $\begin{array}{l}\text { Representative } \\
\text { institutions }\end{array}$ & $\begin{array}{l}\text { Shared- } \\
\text { rule }\end{array}$ & $\begin{array}{c}\text { Constitutional } \\
\text { power } \\
\text { sharing }\end{array}$ & $\begin{array}{l}\text { Legislative } \\
\text { power } \\
\text { sharing }\end{array}$ & $\begin{array}{l}\text { Executive } \\
\text { power } \\
\text { sharing }\end{array}$ & $R A I$ \\
\hline \multirow[t]{2}{*}{ Albania } & $1992-1999$ & 0 & 0 & 0 & 0 & 0 & 0 & 0 & 0 & 0 \\
\hline & $2000-2006$ & 2.0 & 1.0 & 0 & 1.0 & 0 & 0 & 0 & 0 & 2.0 \\
\hline \multirow[t]{3}{*}{ Australia } & $1950-1973$ & 15.3 & 6.3 & 6.0 & 3.0 & 3.4 & 0.8 & 1.1 & 1.5 & 18.6 \\
\hline & 1974-1988 & 16.6 & 6.6 & 6.5 & 3.5 & 4.0 & 0.9 & 1.3 & 1.8 & 20.6 \\
\hline & $1989-2006$ & 19.0 & 7.0 & 8.0 & 4.0 & 4.5 & 1.0 & 1.5 & 2.0 & 23.5 \\
\hline \multirow[t]{2}{*}{ Austria } & $1950-1983$ & 16.0 & 8.0 & 4.0 & 4.0 & 4.0 & 2.0 & 1.0 & 1.0 & 20.0 \\
\hline & $1984-2006$ & 16.0 & 8.0 & 4.0 & 4.0 & 6.0 & 4.0 & 1.0 & 1.0 & 22.0 \\
\hline \multirow[t]{7}{*}{ Belgium } & $1950-1969$ & 7.0 & 4.0 & 2.0 & 1.0 & 3.5 & 2.0 & 1.5 & 0 & 10.5 \\
\hline & $1970-1979$ & 9.0 & 5.0 & 2.0 & 2.0 & 3.5 & 2.0 & 1.5 & 0 & 12.5 \\
\hline & 1980 & 13.0 & 8.0 & 2.0 & 3.0 & 3.5 & 2.0 & 1.5 & 0 & 16.5 \\
\hline & 1981-1988 & 17.0 & 12.0 & 2.0 & 3.0 & 3.5 & 2.0 & 1.5 & 0 & 20.5 \\
\hline & 1989-1992 & 21.0 & 12.0 & 6.0 & 3.0 & 5.5 & 2.0 & 1.5 & 2.0 & 26.5 \\
\hline & $1993-1994$ & 21.0 & 12.0 & 6.0 & 3.0 & 7.5 & 4.0 & 1.5 & 2.0 & 28.5 \\
\hline & $1995-2006$ & 23.0 & 12.0 & 6.0 & 5.0 & 7.5 & 4.0 & 1.5 & 2.0 & 30.5 \\
\hline Bosnia and & 1995-1999 & 30.0 & 12.0 & 12.0 & 6.0 & 6.0 & 4.0 & 2.0 & 0 & 36.0 \\
\hline Herzegovina & $2000-2006$ & 29.8 & 11.9 & 11.9 & 6.0 & 6.0 & 4.0 & 2.0 & 0 & 35.8 \\
\hline Bulgaria & $1991-2006$ & 1.0 & 1.0 & 0 & 0 & 0 & 0 & 0 & 0 & 1.0 \\
\hline \multirow[t]{2}{*}{ Canada } & $1950-1998$ & 20.8 & 8.3 & 8.0 & 4.5 & 6.0 & 4.0 & 0 & 2.0 & 26.8 \\
\hline & 1999-2006 & 20.5 & 8.0 & 8.0 & 4.5 & 6.0 & 4.0 & 0 & 2.0 & 26.5 \\
\hline Croatia & $1993-2006$ & 9.0 & 4.0 & 1.0 & 4.0 & 1.0 & 0 & 1.0 & 0 & 10.0 \\
\hline Cyprus & $1960-2006$ & 0 & 0 & 0 & 0 & 0 & 0 & 0 & 0 & 0 \\
\hline Czech & 1993-1999 & 0 & 0 & 0 & 0 & 0 & 0 & 0 & 0 & 0 \\
\hline Republic & 2000-2006 & 8.0 & 4.0 & 0 & 4.0 & 0 & 0 & 0 & 0 & 8.0 \\
\hline \multirow[t]{3}{*}{ Denmark } & $1950-1969$ & 5.1 & 4.0 & 0.1 & 1.0 & 0 & 0 & 0 & 0 & 5.2 \\
\hline & 1970-1978 & 10.1 & 4.0 & 2.1 & 4.0 & 0 & 0 & 0 & 0 & 10.1 \\
\hline & 1979-2006 & 10.2 & 4.1 & 2.1 & 4.0 & 0.1 & 0.04 & 0.02 & 0.02 & 10.3 \\
\hline Estonia & $1992-2006$ & 0 & 0 & 0 & 0 & 0 & 0 & 0 & 0 & 0 \\
\hline
\end{tabular}




\begin{tabular}{|c|c|c|c|c|c|c|c|c|c|c|}
\hline Country & Year & Self-rule & $\begin{array}{l}\text { Policy } \\
\text { scope }\end{array}$ & $\begin{array}{c}\text { Tax } \\
\text { power }\end{array}$ & $\begin{array}{l}\text { Representative } \\
\text { institutions }\end{array}$ & $\begin{array}{l}\text { Shared- } \\
\text { rule }\end{array}$ & $\begin{array}{c}\text { Constitutional } \\
\text { power } \\
\text { sharing }\end{array}$ & $\begin{array}{l}\text { Legislative } \\
\text { power } \\
\text { sharing }\end{array}$ & $\begin{array}{c}\text { Executive } \\
\text { power } \\
\text { sharing }\end{array}$ & RAI \\
\hline \multirow[t]{2}{*}{ Finland } & $1950-1993$ & 1.1 & 1.0 & 0 & 0 & 0 & 0 & 0 & 0 & 1.1 \\
\hline & 1994-2006 & 5.1 & 3.0 & 0 & 2.0 & 0 & 0 & 0 & 0 & 5.1 \\
\hline \multirow[t]{6}{*}{ France } & $1950-1958$ & 6.0 & 4.0 & 1.0 & 1.0 & 0 & 0 & 0 & 0 & 6.0 \\
\hline & $1959-1971$ & 8.0 & 5.0 & 1.0 & 2.0 & 0 & 0 & 0 & 0 & 8.0 \\
\hline & 1972-1981 & 10.0 & 6.0 & 2.0 & 2.0 & 0 & 0 & 0 & 0 & 10.0 \\
\hline & $1982-1985$ & 16.1 & 8.0 & 2.0 & 6.1 & 0.05 & 0 & 0 & 0.05 & 16.2 \\
\hline & 1986-1990 & 18.0 & 8.0 & 2.0 & 8.0 & 0.05 & 0 & 0 & 0.05 & 18.1 \\
\hline & $1991-2006$ & 18.0 & 8.0 & 2.0 & 8.0 & 0 & 0 & 0 & 0 & 18.0 \\
\hline Germany & $1950-2006$ & 25.0 & 12.0 & 5.0 & 8.0 & 8.0 & 4.0 & 2.0 & 2.0 & 33.0 \\
\hline \multirow[t]{3}{*}{ Greece } & $1950-1985$ & 1.0 & 1.0 & 0 & 0 & 0 & 0 & 0 & 0 & 1.0 \\
\hline & 1986-1993 & 3.0 & 2.0 & 0 & 1.0 & 0 & 0 & 0 & 0 & 3.0 \\
\hline & $1994-2006$ & 11.0 & 6.0 & 0 & 5.0 & 0 & 0 & 0 & 0 & 11.0 \\
\hline \multirow[t]{2}{*}{ Hungary } & $1990-1998$ & 9.0 & 4.0 & 1.0 & 4.0 & 0 & 0 & 0 & 0 & 9.0 \\
\hline & $1999-2006$ & 12.0 & 6.0 & 1.0 & 5.0 & 0 & 0 & 0 & 0 & 12.0 \\
\hline Iceland & $1950-2006$ & 0 & 0 & 0 & 0 & 0 & 0 & 0 & 0 & 0 \\
\hline \multirow[t]{3}{*}{ Ireland } & $1950-1986$ & 0 & 0 & 0 & 0 & 0 & 0 & 0 & 0 & 0 \\
\hline & 1987-1993 & 1.0 & 1.0 & 0 & 0 & 0 & 0 & 0 & 0 & 1.0 \\
\hline & $1994-2006$ & 3.0 & 1.0 & 0 & 2.0 & 0 & 0 & 0 & 0 & 3.0 \\
\hline \multirow[t]{8}{*}{ Italy } & $1950-1963$ & 10.4 & 5.6 & 0 & 4.8 & 1.2 & 0.2 & 1.0 & 0 & 11.6 \\
\hline & $1964-1971$ & 11.0 & 6.0 & 0 & 5.0 & 1.3 & 0.3 & 1.0 & 0 & 12.3 \\
\hline & $1972-1975$ & 15.5 & 7.5 & 0 & 8.0 & 2.0 & 1.0 & 1.0 & 0 & 17.5 \\
\hline & 1976-1988 & 17.0 & 9.0 & 0 & 8.0 & 2.0 & 1.0 & 1.0 & 0 & 19.0 \\
\hline & 1989-1992 & 17.0 & 9.0 & 0 & 8.0 & 3.0 & 1.0 & 1.0 & 1.0 & 20.0 \\
\hline & 1993-1997 & 19.0 & 9.0 & 2.0 & 8.0 & 3.0 & 1.0 & 1.0 & 1.0 & 22.0 \\
\hline & $1998-2000$ & 19.3 & 9.0 & 2.3 & 8.0 & 3.0 & 1.0 & 1.0 & 1.0 & 22.3 \\
\hline & $2001-2006$ & 23.0 & 12.0 & 3.0 & 8.0 & 3.0 & 1.0 & 1.0 & 1.0 & 26.0 \\
\hline Japan & $1950-2006$ & 8.0 & 4.0 & 0 & 4.0 & 0 & 0 & 0 & 0 & 8.0 \\
\hline Latvia & $1990-2006$ & 0 & 0 & 0 & 0 & 0 & 0 & 0 & 0 & 0 \\
\hline
\end{tabular}




\begin{tabular}{|c|c|c|c|c|c|c|c|c|c|c|}
\hline Country & Year & Self-rule & $\begin{array}{l}\text { Policy } \\
\text { scope }\end{array}$ & $\begin{array}{c}\text { Tax } \\
\text { power }\end{array}$ & $\begin{array}{l}\text { Representative } \\
\text { institutions }\end{array}$ & $\begin{array}{l}\text { Shared- } \\
\text { rule }\end{array}$ & $\begin{array}{c}\text { Constitutional } \\
\text { power } \\
\text { sharing }\end{array}$ & $\begin{array}{l}\text { Legislative } \\
\text { power } \\
\text { sharing }\end{array}$ & $\begin{array}{c}\text { Executive } \\
\text { power } \\
\text { sharing }\end{array}$ & RAI \\
\hline \multirow[t]{2}{*}{ Lithuania } & 1992-1994 & 0 & 0 & 0 & 0 & 0 & 0 & 0 & 0 & 0 \\
\hline & $1995-2006$ & 4.0 & 0 & 1.0 & 0 & 0 & 0 & 0 & 0 & 5.0 \\
\hline Luxembourg & $1950-2006$ & 0 & 0 & 0 & 0 & 0 & 0 & 0 & 0 & 0 \\
\hline Macedonia & 1991-2006 & 0 & 0 & 0 & 0 & 0 & 0 & 0 & 0 & 0 \\
\hline Malta & $1964-2006$ & 0 & 0 & 0 & 0 & 0 & 0 & 0 & 0 & 0 \\
\hline Netherlands & $1950-2006$ & 6.0 & 4.0 & 1.0 & 4.0 & 5.5 & 4.0 & 1.5 & 0 & 11.5 \\
\hline \multirow[t]{3}{*}{ New Zealand } & $1950-1973$ & 0 & 0 & 0 & 0 & 0 & 0 & 0 & 0 & 0 \\
\hline & 1974-1988 & 6.0 & 2.0 & 2.0 & 2.0 & 0 & 0 & 0 & 0 & 6.0 \\
\hline & $1989-2006$ & 8.0 & 2.0 & 2.0 & 4.0 & 0 & 0 & 0 & 0 & 8.0 \\
\hline \multirow[t]{2}{*}{ Norway } & $1950-1974$ & 6.0 & 4.0 & 0 & 2.0 & 0 & 0 & 0 & 0 & 6.0 \\
\hline & $1975-2006$ & 10.0 & 4.0 & 2.0 & 4.0 & 0 & 0 & 0 & 0 & 10.0 \\
\hline \multirow[t]{2}{*}{ Poland } & 1990-1998 & 2.0 & 1.0 & 0 & 1.0 & 0 & 0 & 0 & 0 & 2.0 \\
\hline & 1999-2006 & 8.0 & 4.0 & 0 & 4.0 & 0 & 0 & 0 & 0 & 8.0 \\
\hline Portugal & 1976-2006 & 2.4 & 1.1 & 0.1 & 1.1 & 0.1 & 0.05 & 0 & 0.05 & 2.5 \\
\hline \multirow[t]{4}{*}{ Romania } & 1991-1993 & 6.0 & 4.0 & 0 & 2.0 & 0 & 0 & 0 & 0 & 6.0 \\
\hline & 1994-1995 & 8.0 & 4.0 & 2.0 & 2.0 & 0 & 0 & 0 & 0 & 8.0 \\
\hline & 1996-1997 & 10.0 & 4.0 & 2.0 & 4.0 & 0 & 0 & 0 & 0 & 10.0 \\
\hline & $1998-2006$ & 13.0 & 5.0 & 2.0 & 6.0 & 0 & 0 & 0 & 0 & 13.0 \\
\hline Russian & 1993-1995 & 13.0 & 8.0 & 4.0 & 1.0 & 8.0 & 4.0 & 2.0 & 2.0 & 21.0 \\
\hline \multirow[t]{2}{*}{ Federation } & $1996-2004$ & 16.0 & 8.0 & 4.0 & 4.0 & 8.0 & 4.0 & 2.0 & 2.0 & 24.0 \\
\hline & $2005-2006$ & 13.0 & 8.0 & 4.0 & 1.0 & 8.0 & 4.0 & 2.0 & 2.0 & 21.0 \\
\hline Serbia and & 1992-2002 & 18.8 & 8.3 & 6.5 & 4.0 & 4.5 & 3.25 & 1.25 & 0 & 23.3 \\
\hline Montenegro & 2003-2006 & 18.8 & 8.3 & 6.5 & 4.0 & 3.3 & 3.3 & 0 & 0 & 22.1 \\
\hline Slovak & 1992-1995 & 0 & 0 & 0 & 0 & 0 & 0 & 0 & 0 & 0 \\
\hline \multirow[t]{2}{*}{ Republic } & 1996-2001 & 1.0 & 0 & 0 & 0 & 0 & 0 & 0 & 0 & 1.0 \\
\hline & $2002-2006$ & 8.0 & 4.0 & 0 & 4.0 & 0 & 0 & 0 & 0 & 8.0 \\
\hline Slovenia & 1991-2006 & 0 & 0 & 0 & 0 & 0 & 0 & 0 & 0 & 0 \\
\hline
\end{tabular}




\begin{tabular}{|c|c|c|c|c|c|c|c|c|c|c|}
\hline Country & Year & Self-rule & $\begin{array}{l}\text { Policy } \\
\text { scope }\end{array}$ & $\begin{array}{c}\text { Tax } \\
\text { power }\end{array}$ & $\begin{array}{l}\text { Representative } \\
\text { institutions }\end{array}$ & $\begin{array}{l}\text { Shared- } \\
\text { rule }\end{array}$ & $\begin{array}{c}\text { Constitutional } \\
\text { power } \\
\text { sharing }\end{array}$ & $\begin{array}{l}\text { Legislative } \\
\text { power } \\
\text { sharing }\end{array}$ & $\begin{array}{c}\text { Executive } \\
\text { power } \\
\text { sharing }\end{array}$ & RAI \\
\hline \multirow[t]{6}{*}{ Spain } & 1978 & 8.0 & 4.0 & 2.0 & 2.0 & 2.0 & 1.0 & 1.0 & 0 & 10.0 \\
\hline & 1979 & 9.4 & 4.9 & 2.5 & 2.0 & 2.3 & 1.2 & 1.1 & 0 & 11.7 \\
\hline & 1980 & 13.6 & 6.8 & 3.4 & 3.4 & 2.9 & 1.7 & 1.2 & 0 & 16.5 \\
\hline & 1981 & 20.2 & 10.1 & 5.0 & 5.1 & 3.9 & 2.5 & 1.4 & 0 & 24.1 \\
\hline & 1982-1993 & 24.0 & 12.0 & 6.0 & 6.0 & 5.5 & 3.0 & 1.5 & 1.0 & 29.5 \\
\hline & $1994-2006$ & 24.0 & 12.0 & 6.0 & 6.0 & 6.5 & 3.0 & 1.5 & 2.0 & 30.5 \\
\hline \multirow[t]{2}{*}{ Sweden } & $1950-1970$ & 8.0 & 4.0 & 2.0 & 2.0 & 3.5 & 2.0 & 1.5 & 0 & 11.5 \\
\hline & 1971-2006 & 10.0 & 4.0 & 2.0 & 4.0 & 0 & 0 & 0 & 0 & 10.0 \\
\hline Switzerland & $1950-2006$ & 20.0 & 8.0 & 8.0 & 4.0 & 2.5 & 0 & 1.5 & 1.0 & 22.5 \\
\hline Turkey & $1950-2006$ & 5.0 & 4.0 & 0 & 1.0 & 0 & 0 & 0 & 0 & 5.0 \\
\hline United & $1950-1963$ & 9.4 & 4.3 & 1.0 & 4.1 & 0 & 0 & 0 & 0 & 9.4 \\
\hline \multirow[t]{8}{*}{ Kingdom } & 1964-1971 & 9.5 & 4.4 & 1.0 & 4.1 & 0 & 0 & 0 & 0 & 9.5 \\
\hline & $1972-1993$ & 8.9 & 4.0 & 1.0 & 3.9 & 0 & 0 & 0 & 0 & 8.9 \\
\hline & 1994-1996 & 9.8 & 4.9 & 1.0 & 3.9 & 0 & 0 & 0 & 0 & 9.8 \\
\hline & 1997-1998 & 8.6 & 4.3 & 1.0 & 3.3 & 0 & 0 & 0 & 0 & 8.6 \\
\hline & 1999 & 12.0 & 6.1 & 1.0 & 4.8 & 0.5 & 0.3 & 0.1 & 0.1 & 12.5 \\
\hline & 2000 & 12.5 & 6.3 & 1.1 & 5.1 & 0.5 & 0.3 & 0.1 & 0.1 & 13.0 \\
\hline & $2001-2002$ & 12.6 & 6.3 & 1.1 & 5.2 & 0.5 & 0.3 & 0.1 & 0.1 & 13.1 \\
\hline & $2003-2006$ & 12.3 & 6.1 & 1.1 & 5.0 & 0.5 & 0.3 & 0.1 & 0.1 & 12.7 \\
\hline United States & $1950-2006$ & 20.0 & 8.0 & 8.0 & 4.0 & 6.5 & 4.0 & 1.5 & 1.0 & 26.5 \\
\hline
\end{tabular}




\section{Sources}

\section{General}

Alesina, Alberto and Enrico Spolaore (2003). The Size of Nations. Cambridge, MA: MIT Press.

Bache, Ian, and Matthew Flinders (2005). Multilevel Governance. Oxford: OUP.

Baldi, Bruno (1999). Beyond the Federal-Unitary Dichotomy. Berkeley: University of California, Working Paper of the Institute of Governmental Studies.

Bolton, Patrick, and Gerard Roland (1997). "The Breakup of Nations: A Political Economy Analysis," Quarterly Journal of Economics, 112, 4, 1057-90.

Brancati, Dawn (2006). “Decentralization: Fueling or Dampening the Flames of Ethnic Conflict and Secessionism," International Organization, 60, 651-685.

Brancati, Dawn (forthcoming). "The Origins and Strength of Regional Parties," British Journal of Political Science.

Braun, Dietmar (ed.) (2000). Public Policy and Federalism. Aldershot: Ashgate.

Burgess, Michael (2006). Comparative Federalism: Theory and Practice. London: Routledge.

Castles, Frank G. (1999). “Decentralization and the Post-War Economy," European Journal of Political Research, 36, 27-53.

Christopoulos, Dimitrios C. (2006). "Governance Capacity and Regionalist Dynamics." Regional and Federal Studies, 16, 4, 363-83.

De Winter, Lieven, and Huri Türsan (eds.) (1998). Regionalist Parties in Western Europe. New York: Routledge.

Dikshit, Ramesh D. (1975). The Political Geography of Federalism. An Inquiry into Origins and Stability. Dehli: MacMillan.

Duchacek, Ivo D. (1970). Comparative Federalism. The Territorial Dimension of Politics. New York, United States of America, Holt, Rinehart and Winston, Inc.

Elazar, Daniel J. (Ed) (1991). Federal Systems of the World. A Handbook of Federal, Confederal and Autonomy Arrangements. Essex, U.K.: Longman Group.

Elazar, Daniel J. (1987). Exploring Federalism. Tuscaloosa, AL: The University of Alabama Press.

Elazar, Daniel J. (1997). “Contrasting Unitary and Federal Systems," International Political Science Review, $18,237-51$.

Elazar, Daniel J.(1993). “International and Comparative Federalism," Political Science and Politics, 26, 190195.

Esman, Milton J., (ed.). 1977. Ethnic Conflict in the Western World. Ithaca, NY: Cornell University Press.

Fearon, J.D. (2003). "Ethnic and Cultural Diversity by Country," Journal of Economic Growth, 8, p. 195-222

Feynman, Richard (1965). The Character of Physical Law. Cambridge, MA: MIT.

Hooghe, Liesbet and Gary Marks (2001). Multi-Level Governance and European Integration. Lanham, MD.: Rowman \& Littlefield Publishers.

Hooghe, Liesbet and Gary Marks (2003). "Unraveling the Central State, But How? Types of Multilevel Governance." American Political Science Review, 97, 2, 233-44.

Jeffery, Charlie and David Heald eds. (2006). Devolution \& Electoral Politics. Manchester: Manchester University Press.

John, Peter (2001). Local Governance in Western Europe. Sage Publication, London, United Kingdom.

Jolly, Seth (2006). A Europe of Regions? Regional Integration, Subnational Mobilization and the Optimal Size of States. Durham: Duke University, NC, Doctoral Dissertation in Political Science.

Keating, Michael (1997). The New Regionalism in Western Europe. Territorial Politics and the European State. Aldershot: Edward Elgar.

Keating, Michael (2001a). Nations Against the State. The New Politics of Nationalism inQuebec, Catalonia and Scotland. Houndsmill: Palgrave.

Keating, Michael (2001b). Plurinational Democracy. Stateless Nations in a Post-Sovereignty Era. Oxford: Oxford University Press. 
King, Preston (1982). Federalism and Federation. Baltimore: The John Hopkins University Press.

Lane, Jan-Erik and Svante Ersson (1999). Politics and Society in Western Europe. London: Sage Publications.

Lane, Jan-Erik and Svante Ersson (2000). The New Institutional Politics. Performance and Outcomes. London, United Kingdom, Routledge.

Lijphart, Arend (1999). Patterns of Democracy: Government Forms and Performance in Thirty-Six Countries. New Haven: Yale University Press.

Marks, Gary, and Liesbet Hooghe (2000). "Optimality and Authority: A Critique of Neoclassical Theory," Journal of Common Market Studies, 38, 5, 795-816.

McKay, David (2007). "William Riker on Federalism: Sometimes Wrong but More Right than Anyone Else?" Regional and Federal Studies, 14, 2, 167-86.

Oates, Wallace (1972). Fiscal Federalism. New York: Harcourt Brace Javanovich.

OECD (1999). Taxing Powers of State and Local Government. OECD Tax Policy Studies No. 1. Paris, France.

Page, Edward C. (1991). Localism and Centralism in Europe. The Political and Legal Bases of Local SelfGovernment. Oxford: Oxford University Press.

Page, Edward C. and Michael J. Goldsmith (1987). Central and Local Government Relations. A Comparative Analysis of West European Unitary States. London, United Kingdom, Sage Publications.

Pratchett, Lawrence (2004). “Local Autonomy, Local Democracy and the 'New Localism.' Political Studies, 52: 358-75.

Riker, William H. (1964). Federalism: Origin, Operation, Significance. Boston: Little Brown.

Riker, William H. (1975). “Federalism," In: Fred I. Greenstein and Nelson W. Polsby (Ed) Governmental Institutions and Processes. Handbook of Political Science, 93-172.

Rodden, Jonathan (2002). "The Dilemma of Fiscal Federalism: Grants and Fiscal Performance around the World," American Journal of Political Science, 46, 3, 670-87.

Rodden, Jonathan (2004). “Comparative Federalism and Decentralization: On Meaning and Measurement," Comparative Politics, 36, 481-499.

Rodden, Jonathan, and Erik Wibbels (2002). "Beyond the Fiction of Federalism: Macroeconomic Management in Multitiered Systems," World Politics, 54, 494-531.

Schakel, Arjan H. (2007). "Validation of the Regional Authority Index," paper to be presented at the Politicologenetmaal May 31 - June 1, Antwerp.

Sharpe, Jim L. (ed) (1993). The Rise of Meso Government in Europe. Sage Publications, London, United Kingdom.

Simon, James [s.d]. "Financing Multi-level Government," Journal of Finance and Management of Public Services, 4, 1, 18-32.

Stegarescu, Dan (2005). "Public Sector Decentralisation: Measurement, Concepts and Recent International Trends," Fiscal Studies, 26 (3), 301-333.

Treisman, Daniel (2002). Defining and Measuring Decentralization: A Global Perspective, unpublished manuscript.

Van Houten, Pieter (2003). "Globalization and Demands for Regional Autonomy in Europe," in Miles Kahler and David Lake eds., Governance in a Global Economy, Princeton, NJ: PUP.

Volden, Craig (2004). "Origin, Operation, and Significance: The Federalism of William H. Riker," Publius, 34, 4: 89-107.

Watts, Ronald L. (1999). Comparing Federal Systems. Second Edition. Montreal: McGill-Queen's University Press.

Wibbels, Erik (2006). "Madison in Bagdad? Decentralization and Federalism in Comparative Politics." Annual Review of Political Science, 165-88.

Woldendorp, Jaap, Hans Keman and Ian Budge (2000). Party Government in 48 Democracies (1945-1998). Composition-Duration-Personnel. Dordrecht: Kluwer Academic Press. 


\section{Countries: general}

Agranoff, Robert (2004). "Autonomy, Devolution and Intergovernmental Relations," Regional and Federal Studies, 14, 1, p. 25-65.

Batley, Richard and Gerry Stoker (Eds) (1991). Local Government in Europe. Trends and Developments. MacMillan, Houdsmills, United Kingdom.

Bennet, Robert J. (Ed) (1993). Local Government in the New Europe. Belhaven Press, London, United Kingdom.

Brusis, Martin (2005). “The Instrumental Use of European Union Conditionaly: Regionalization in the Czech Republic and Slovakia." East European Politics and Societies, 19, 291-316.

Chandler, James A. (Ed) (1993). Local Government in Liberal Democracies. An Introductionary Survey. Routledge, London, United Kingdom.

Committee of the Regions (2003). Devolution Process in the European Union and the Candidate Countries. Devolution Schemes. Situation in 2003. Twenty-eight countries. Committee of the Regions, Brussel, Belgium.

Council of Europe (1996-2006). Structure and Operation of Local and Regional Democracy. Forty Country Reports. Council of Europe Publishing, Strasbourg, France.

Council of Europe (1998). Regionalisation and its effects on Local Self-Government. Local and Regional Authorities in Europe, No. 64. Council of Europe Publishing, Strasbourg, France.

Dabla-Norris Era and Paul Wade (2002). "The Challenge of Fiscal Decentralization in Transition Countries," International Monetary Fund Working Paper. WP/02/103.

Dabla-Norris Era and Paul Wade (2002). "The Challenge of Fiscal Decentralization in Transition Countries," International Monetary Fund Working Paper. WP/02/103.

Elazar, Daniel J. (Ed) (1991). Federal Systems of the World. A Handbook of Federal, Confederal and Autonomy Arrangements. Essex, United Kingdom, Longman Group.

Filippov, Mikhail, Peter C. Ordeshook, and Olga Shvetsova (2004). Designing Federalism. A Theory of SelfSustainable Federal Institutions. Cambridge University Press, Cambridge, United Kingdom.

Friedrich Ebert Stiftung (2001). Local Self Government and Decentralization in South-East Europe. Proceedings of the workshop held in Zagreb, Croatia, April 6 2001. Friedrich Ebert Stiftung, Zagreb, Croatia.

Griffiths, Ann L. (Ed) (2002). Handbook of Federal Countries, 2002. Montreal, McGill-Queen's University Press.

Harloff, Eileen Martin (1987). The Structure of Local Government in Europe. Survey of 29 Countries. International Union of Local Authorities, The Hague, Netherlands.

Hesse, Joachim Jens (Ed) (1991). Local Government and Urban Affairs in International Perspective. Analyses of Twenty Western Industrialized Countries. Nomos Verlagsgesellschaft, Baden-Baden, Germany.

Högye, Mihály (Ed) (2000). Local and Regional Tax Administration in Transition Countries. Local Government and Public Sector Reform Initiative, Budapest, Hungary.

Hooghe, Liesbet and Gary Marks (2001). Multi-Level Governance and European Integration. Rowman \& Littlefield Publishers, Oxford, United Kingdom.

Horváth, Tamás M. (Ed) (2000). Decentralization: Experiments and Reforms. Volume 1. Local Government and Public Sector Reform Initiative, Budapest, Hungary.

Hueglin, Thomas O. and Alan Fenna (2006). Comparative Federalism. A Systematic Inquiry. Broadview Press, Quebec, Canada.

Hughes, James, Gwendolyn Sasse and Claire Gordon (2004). Europeanization and Regionalization in the EU's Enlargement to Central and Eastern Europe. The Myth of Conditionality. Palgrave MacMillan, Houndmills, United Kingdom, p. 30-60 and 118-140.

Humes, Samuel (1991). Local Governance and National Power. A Worldwide Comparison of Tradition and Change in Local Government. International Union of Local Authorities, The Hague, Netherlands.

Humes, Samuel and Eileen Martin (1969). The Structure of Local Government. A Comparative Survey of 81 Countries. International Union of Local Authorities, The Hague, Netherlands.

Illner, Michal (1998). Territorial Decentralization: An Obstacle to Democratic Reform in Central and Eastern Europe? In: Jonathan D. Kimball (Ed) The Transfer of Power. Decentralization in Central and Eastern Europe. Local Government and Public Service Reform Initiative, Budapest, Hungary, p. 7-42. 
Jeffery, Charlie (Ed) (1997). The Regional Dimension of the European Union. Towards a Third Level in Europe? Frank Cass, London, United Kingdom.

John, Peter (2001). Local Governance in Western Europe. Sage Publication, London, United Kingdom.

Jones, Barry and Michael Keating (Eds) (1995). The European Union and the Regions. Oxford University Press, Oxford, United Kingdom.

Kandeva, Emilia (Ed) (2001). Stabilization of Local Governments. Local Governments in Central and Eastern Europe. Volume 2. Local Government and Public Sector Reform Initiative, Budapest, Hungary.

Keating, Michael and Barry Jones (Eds) (1985). Regions in the European Community. Clarendon Press, Oxford, United Kingdom.

Keating, Michael and James Hughes (Eds) (2002). The Regional Challenge in Central and Eastern Europe. Territorial Restructuring and European Integration. P.I.E.-Peter Lang, Brussel, Belgium.

Loughlin, John with the collaboration of Eliseo Aja, Udo Bullman, Frank Hendriks, Anders Lidström and Daniel-L. Seiler (2001). Subnational Democracy in the European Union. Challenges and Opportunities. Oxford University Press, Oxford, United Kingdom.

Marcou, Gérard (Ed) (2002). Regionalization for Development and Accession to the European Union: A Comparative Perspective. Local Government and Public Service Reform Initiative, Budapest, Hungary.

Mény, Yves and Vincent Wright (Eds) (1985). Centre-Periphery Relations in Western Europe. George Allen \& Unwin, London, United Kingdom.

Munteanu, Igor and Victor Popa (Eds) (2001). Developing New Rules in the Old Environment. Volume 3. Local Governments in the Eastern Europe, in the Caucasus and Central Asia. Local Government and Public Service Reform Initiative, Budapest, Hungary.

O'Dwyer, Conor (2006). "Reforming Regional Governance in East Central Europe: Europeanization or Domestic Politics as Usual?" East European Politics and Societies, 20, 219-53.

OECD (1997). Managing Across Levels of Government. Paris, France.

OECD (1999). Taxing Powers of State and Local Government. OECD Tax Policy Studies No. 1. Paris, France.

OECD (2001). Fiscal Design Across Levels of Government. Year 2000 Surveys. Paris, France.

OECD (2002). Fiscal Decentralization in EU Applicant States and Selected EU Member States. Report prepared for the workshop on "Decentralisation: trends, perspective and issues at the threshold of EU enlargement," held in Denmark, 10-11 October 2002.

Page, Edward and Michael J. Goldsmith (Eds) (1987). Central and Local Government Relations. A Comparative Analysis of West European Unitary States. Sage Publications, London, United Kingdom.

Sharpe, Jim L. (Ed) (1993). The Rise of Meso Government in Europe. Sage Publications, London, United Kingdom.

Soós, Gábor (Ed) (2006). The State of Local Democracy in Central Europe. Local Government and Public Service Reform Initiative, Budapest, Hungary.

Soós, Gábor, Gábor Tóka, and Glen Wright (Eds) (2002). The State of Local Democracy in Central Europe. Local Government and Public Service Reform Initiative, Budapest, Hungary.

Swenden, Wilfried (2006). Federalism and Regionalism in Western Europe. A Comparative and Thematic Analysis. Palgrave Macmillan, Houndsmill, United Kingdom.

Symons, Craig (Ed) (1984). Comparative Local Government. Country Papers. International Perspectives No. 9, Australian Development Assistance Bureau Department of Foreign Affairs, International Training Institute, Middle Head, Australia.

Ter-Minassian, Teresa (Ed) (1997). Fiscal Federalism in Theory and Practice. International Monetary Fund, Washington, United States of America.

UNDP (2005). Fiscal Decentralization in Transition Economies: Case Studies from the Balkans and Caucasus. UNDP, Bratislava, Slovakia.

Van Ginderachter, Jef (1993). Part II: Summary of the National Contributions. In: Christian Engel and Jef Van Ginderachter (Eds) Trends in Regional and Local Government in the European Community. Trans European Policy Studies Association, Acco, Leuven, Belgium, p. 51-101. 


\section{Country-specific}

Adelberger, Karen (2001). "Federalism and Its Discontents: Fiscal and Legislative Power-sharing in Germany, 1948-99," Regional and Federal Studies, 11, 2, p. 43-68.

Arter, David (2001). "Regionalization in the European Peripheries: The Case of Northern Norway and Finnish Lapland," Regional and Federal Studies, 11, 2, p. 91-114.

Ayres, Sarah and Graham Pearce (2004). "Central Government Responses to Governance Change in the English Regions," Regional and Federal Studies, 14, 2, p. 255-280.

Bache, Ian (2005). “Europeanization and Britain: Towards Multilevel Governance?" Paper presented at the European Studies Association Meeting, Austin, TX, March 2005.

Baier, Gerald (2005). "The EU's Constitutional Treaty: Federalism and Intergovernmental Relations Lessons from Canada," Regional and Federal Studies, 15, 2, p. 205-223.

Bauer, Michael (2006). "The German Länder: Heading for a Differentiated Theory of Regional Elite Preferences for European Integration." Regional and Federal Studies, 16, 1, 21-41.

Baun, Michael, and Dan Marek (2006). "Regional Policy and Decentralization in the Czech Republic." Regional and Federal Studies, 16, 4, 409-28.

Bialasiewicz, Luiza (2002). "Upper Silesia: Rebirth of a Regional Identity in Poland," Regional and Federal Studies, 12, 2, p. 111-132.

Bitušíková, Alexandra (2002). “Slovakia: An Anthropological Perspective on Regional Reform," Regional and Federal Studies, 12, 2, p. 41-64.

Bolleyer, Nicole (2006). "Intergovernmental Arrangements in Spanish and Swiss Federalism: The Impact of Power-Concentrating and Power-Sharing Executives on Intergovernmental Institutionalization." Regional and Federal Studies, 16, 4, 385-408.

Börzel, Tanja A. (2005). "What Can Federalism Teach Us About the European Union? The German Experience," Regional and Federal Studies, 15, 2, p. 245-257.

Casey, Terrence (2002). "Devolution and Social Capital in the British Regions," Regional and Federal Studies, 12, 3, p. 55-78.

Church, Clive and Paolo Dardanelli (2005). "The Dynamics of Confederalism and Federalism: Comparing Switzerland and the EU," Regional and Federal Studies, 15, 2, p. 163-185.

Ciaffi, Andrea (2001). "Multi-Level Governance in Italy: The Case of Marche," Regional and Federal Studies, 11,2 , p. 115-146.

Cole, Michael (2001). "Elections to the Welsh Assembly: Proportionality, Continuity and Change," Regional and Federal Studies, 11, 2, p. 147-163.

Council of Local Authorities for International Relations (CLAIR) (2002). Local Government in Japan. CLAIR, Tokyo, Japan.

Czernielewska, Malgorzata, Christos J. Paraskevopoulos and Jacek Sziachta (2004). “The Regionalization Process in Poland: An Example of 'Shallow' Europeanization?" Regional and Federal Studies, 14, 3, p. 461-495.

Fabrini, Sergio and Daniela Sicurelli (2004). "The Federalization of the EU, the US and 'Compound Republic' Theory: the Convention's Debate," Regional and Federal Studies, 14, 2, p. 232-254.

Fabrini, Sergio and Marco Brunazzo (2003). "Federalizing Italy: The Convergent Effects of Europeanization and Domestic Mobilization," Regional and Federal Studies, 13, 1, p. 100-120.

Ferry, Martin and Irene Mcmaster (2005), "Implementing Structural Funds in Polish and Czech Regions: Convergence, Variation, Empowerment?" Regional and Federal Studies, 15, 1, p. 19-39.

Fowler, Brigid (2002). "Hungary: Patterns of Political Conflict over Territorial-Administrative Reform," Regional and Federal Studies, 12, 2, p. 15-40.

Getimis, Panayiotis and Leeda Demetropoulou (2004). “Towards New Forms of Regional Governance in Greece: the Southern Aegean Islands," Regional and Federal Studies, 22, 3, p. 355-378.

Horgan, Gerard W. (2004). "Inter-Institutional Relations in the Devolved Great Britain: Quiet Diplomacy," Regional and Federal Studies, 14, 1, p. 113-135.

Hughes, James (2001). "Managing Secession Potential in the Russian Federation," Regional and Federal Studies, 11, 3, p. 35-68. 
Jackson, Louise J. and Nicholas J. Lynn (2002). “Constructing 'Federal Democracy' in Russia: Debates over Structures of Power in the Regions," Regional and Federal Studies, 12, 1, p. 91-125.

Jeffery, Charlie (2004). "The 2003 Devolved Elections in Scotland, Wales and Northern Ireland: Election Campaigns, Voting Behaviour, Electoral Systems and Representation." Representation, 40.

John, Peter, Adam Tickell, Stephen Musson (2004). “Governing the Mega-Region: Governance and Networks across London and the Southeast of England," Paper presented at the American Political Science Association, Sept 2004.

Kettunen, Pekka and Tarvo Kungla (2005). "Europeanization of Sub-National Governance in Unitary States: Estonia and Finland," Regional and Federal Studies, 15, 3, p. 353-378.

Loughlin, John and Farimah Daftary (1999). Insular Regions and European Integration: Corsica and the Áland Islands Compared. ECMI report 5. European Centre for Minority Issues, Flensburg, Germany.

McCall, Cathal (2001). "The Production of Space and the Realignment of Identity in Northern Ireland," Regional and Federal Studies, 11, 2, p. 1-24.

Nanetti, Raffaella Y., Helena Rato and Miguel Rodrigues (2004). "Institutional Capacity and Reluctant Decentralization in Portugal: the Lisbon and Tagus Valley Region," Regional and Federal Studies, 22, 3 , p. 405-429.

Pálné Kovács Ilona, I., C.J. Parakevopoulous and Gy Horváth (2004). “Institutional ‘Legacies' and the Shaping of Regional Governance in Hungary," Regional and Federal Studies, 14, 3, p. 430-460.

Paterson, Lindsay (2002). "Is Britain Disintegrating? Changing Views of 'Britain' after Devolution," Regional and Federal Studies, 12, 1, p. 21-42.

Pearce, Graham (2001). "Multilevel Governance: Constitutional Reform and British Subnational Government Engagement in Europe," Paper presented at a conference on 'Multilevel governance: Interdisciplinary Perspectives', University of Sheffield, 28-30 June.

Pinnick, Kathryn (2005). “The Greater Altai Initiative: Cross-Border Cooperation on Russia's Southern Periphery," Regional and Federal Studies, 15, 3, p. 379-399.

Porier, Johanne (2002). "Formal Mechanisms of Intergovernmental Relations in Belgium," Regional and Federal Studies, 12, 3, p. 24-54.

Putnam, Robert D. (1993) Making Democracy Work. Civic Traditions in Modern Italy. Princeton University Press, Princeton.

Rees, Nicholas, Brid Quinn and Bernadette Connaughton (2004). “Ireland's Pragmatic Adaptation to Regionalization: the Mid-West Region," Regional and Federal Studies, 14, 3, p. 379-404.

Rotkirch, Holger (1986). "The Demilitarization and Neutralization of the Aland Islands: A Regime 'in European Interests' Withstanding Changing Circumstances," Journal of Peace Research, 23 (4), p. 357 376.

Smith, David J. (2002). "Narva Region within the Estonian Republic: From Autonomism to Accommodation?" Regional and Federal Studies, 12, 2, p. 89-110.

Söderlund, Peter J. (2005). “The Russian Subnational Executives as Institutional Veto Players," Regional and Federal Studies, 15, 1, p. 41-57.

Svensson, Bo and Anders Östhol (2001). “From Government to Governance: Regional Partnerships in Sweden," Regional and Federal Studies, 11, 2, p. 25-42.

Swenden, Wilfired (2005). "What -if anything- can the European Union Learn From Belgian Federalism and Vice Versa," Regional and Federal Studies, 15, 2, p. 187-204.

Vatter, Adrian (2005). “The Transformation of Access and Veto Points in Swiss Federalism," Regional and Federal Studies, 15, 1, p. 1-17.

Wilford, Rick, Roger Mac Ginty, Lizanne Dowds and Gillian Robinson (2003). “Northern Ireland's Devolved Institutions: A Triumph of Hope over Experience?" Regional and Federal Studies, 13, 1, p. 3154.

World Bank (2004a) Albania: Decentralization in Transition (in Two Volumes) Volume I: Summary Report and Matrix of Issues and Options. Report No.: 27885-ALB.

World Bank (2004b) Albania: Decentralization in Transition (in Two Volumes) Volume II: Analytical Report. Report No.: 27885-ALB. 


\section{Internet sites}

Accessed in November and December 2006.

Administrative Divisions of Countries ("Statoids"): http://www.statoids.com/

Assembly of European Regions: http://www.a-e-r.org/

Committee of the Regions: http://www.cor.europa.eu

Council of Europe: http://www.coe.int

Council of European Municipalities and Regions: http://www.ccre.org/

Eurostat "Portrait of the Regions":

http://forum.europa.eu.int/irc/dsis/regportraits/info/data/en/index.htm

Forum of Federations. An International Network on Federalism: http://www.forumfed.org

Hans Böckler Stiftung "Kommunalfinanzen in Europe": http://www.kommunaler-

wettbewerb.de/kofi/seiten/200.html

International Monetary Fund: http://www.imf.org

Local Government and Public Sector Reform Initiative: http://lgi.osi.hu

Local Government Information network: http://www.logincee.org/library.asp

Organization for Economic Co-Operation and Development: http://www.oecd.org

World Bank: http://www.worldbank.org

United Nations Online Network in Public Administration and Finance:

http://www.unpan.org/autoretrieve/regional_focus.asp?region=europe\&focus=local $\% 20$ government

Urban Institute: http://www.urban.org

\section{Sources for each country:}

Albania: Dabla-Norris and Wade (2002) ; Harloff (1987 p. 9-11); Hoxha and Gurraj (2001, p. 194-224); Hoxha (2001 p. 41-88); World Bank (2004a and 2004b).

Australia: Ter-Minassian (1997, p. 175-200); Elazar (1991, p. 22-29 and p. 194-198); Filippov et al. (2004); Hueglin and Fenna (2006); Hume and Martin (1969, p. 641-644); Hesse (1991, p. 13-44); Lynch (1984 p. 1-20); OECD (1997, p. 73-92); Griffiths (2002, p. 30-43); Watts (1999)

Austria: Hesse (1991, p. 387-408); Loughlin (2001, p.117-141); Committee of the Regions (2003); Council of Europe (2000); Elazar (1991, p. 30-36); Filippov et al. (2004); Harloff (1987, p. 12-16); Hooghe and Marks (2001 p. 189-212); Hueglin and Fenna (2006); Humes and Martin (1969, p. 505-509); Jeffery (1997 p. 76-95); OECD (1997, p. 93-106); OECD (1999, p. 19-21) ; Griffiths (2002, p. 44-57); Swenden (2006); Bennet (1993, p. 155-166); Watts (1999)

Belgium: Agranoff (2004, p. 25-65); Committee of the Regions (2003); Council of Europe (1998 and 2006); Hesse (1991, p. 333-352); Sharpe (1993, p. 40-60); Elazar (1991, p. 37-45); Filippov et al. (2004); Harloff (1987, p. 17-22); Loughlin (2001, p. 289-316); Jones and Keating (1995, p. 134-165); Hooghe andMarks (2001, p. 189-212); Hueglin and Fenna (2006); Humes and Martin (1969, p. 510-515); John (2001); Jeffery (1997, p. 41-55); Griffiths (2002, p. 58-73); Mény and Wright (1985, p. 273-299); OECD (1997, p. 107121); OECD (1999, p. 22-26); OECD (2002); Porier(2002); Swenden (2005 and 2006); Engel and Van Ginderachter (1993, p. 51-55); Watts (1999)

Bosnia and Herzegovina: Elazar (1991, p. 349-355); Filippov et al. (2004); Harloff (1987, p. 161-166); Humes and Martin (1969, p. 633-637); Kandeva (2001, p. 89-140); Friedrich Ebert Stiftung (2001, p. 105127); Griffiths (2002, p. 74-89)

Bulgaria: Friedrich Ebert Stiftung (2001, p. 249-272); Ter-Minassian (1997, p. 615-633); Committee of the Regions (2003); Council of Europe (1997); Dabla-Norris and Wade (2002); Kandeva (2001, p. 141-178); Harloff (1987, p. 23-25); Hughes et al. (2004, p. 30-60); Humes and Martin (1969, p. 516-518); Soós (2006, p. 25-162); OECD (2002)

Canada: Baier (2005); Griffiths (2002, p. 105-119); Elazar (1991, p. 57-70); Filippov et al. (2004); Hesse (1991, p. 45-76); Hueglin and Fenna (2006); Humes and Martin (1969, p. 329-335); Chandler (1993, p. 159-187); Ter-Minassian (1997, p. 201-225); OECD (1997, p. 123-145); Watts (1999) 
Croatia: Dabla-Norris and Wade (2002); Council of Europe (1998); Elazar (1991, p. 349-355); Harloff (1987, p. 161-166); Humes and Martin (1969, p. 633-637); Kandeva (2001, p. 179-24); Friedrich Ebert Stiftung (2001, p. 75-104); UNDP (2005, p. 62-91)

Cyprus: Committee of the Regions (2003); Council of Europe (1998); Elazar (1991, p. 80-87); Harloff (1987, p. 27-30); Humes and Martin (1969, p. 519-522)

Czech Republic: Keating and Hughes (2002, p. 89-105); Committee of the Regions (2003); Council of Europe (2004); Dabla-Norris and Wade (2002); Bennet (1993, p. 259-277); Elazar (1991, p. 88-92); Ferry and Mcmaster (2005); Harloff (1987, p. 31-34); Keating and Hughes (2002, p. 78-79); Hughes et al. (2004, p. 30-60); Kimball (1998, p. 7-42); Bennet (1993, p. 246-258); Horváth (2000, p. 255-296); Högye (2000, p. 81-140); OECD (1997, p. 147-163); OECD (1999, p. 27-30) ; OECD (2001); OECD (2002)

Denmark: Agranoff (2004); Page and Goldsmith (1987, p. 46-67); Hesse (1991, p. 13-44); Committee of the Regions (2003); Council of Europe (1998); Elazar (1991, p. 93-97); Sharpe (1993, p. 312-315); Harloff (1987, p. 35-39); Hooghe and Marks (2001, p. 189-212); Humes and Martin (1969, p. 523-526); John (2001); Loughlin (2001, p. 343-363); Batley and Stoker (1991, p. 190-197); OECD (1997, p. 165-177); OECD (1999, p. 31-34); OECD (2002); Barry and Keating (1995, p. 281-288); Engel and Van Ginderachter (1993, p. 56-59)

Estonia: Committee of the Regions (2003); Council of Europe (1999); Dabla-Norris and Wade (2002); Elazar (1991, p. 263-281); Harloff (1987, p. 147-151); Keating and Hughes (2002, p. 79-80); Hughes et al. (2004, p. 30-60); Humes and Martin (1969, p. 628-632); Humes (1991, p. 81-93); Horváth (2000, p. 61114); Kettunen and Kungla (2005); OECD (2001); OECD (2002); Smith (2002); Högye (2000); Soós (2006, p. 163-350); Bennet (1993, p. 292-306)

Finland: Arter (2001); Committee of the Regions (2003); Council of Europe (1998); Elazar (1991, p. 98-101); Harloff (1987, p. 47-51); Hooghe and Marks (2001, p. 189-212); Humes and Martin (1969, p. 527-530); John (2001); Kettunen and Kungla (2005); Loughlin (2001, p. 365-384); Loughlin and Daftary (1999); OECD (1997, p. 179-195); OECD (1999, p. 35-36); Rotkirch (1986)

France: Jones and Keating (1995, p. 166-188); Committee of the Regions (2003); Council of Europe (1998a, p. 57-81); Council of Europe (1998b); Mény and Wright (1985, p. 79-103); Hesse (1991, p. 429-462); Elazar (1991, p. 8-11. 76-79 and 166-167); Harloff (1987, p. 52-61); Hooghe and Marks (2001, p. 189-212); Humes and Martin (1969, p. 531-541); Humes (1991, p. 17-30); Chandler (1993, p. 53-72); John (2001); Batley and Stoker (1991, p. 89-109); Mény and Wright (1985, p. 207-235); Loughlin and Daftary (1999); Loughlin (2001, p.187-210); Sharpe (1993, p. 61-89); Bennet (1993, p. 144-1540; Keating and Jones (1985, p. 191-203); Page and Goldsmith (1987, p. 88-106); OECD (1997, p. 195-212); OECD (2002); Jeffery (1997, p. 117-130); Swenden (2006, p. 16-17); Engel and Van Ginderachter (1993, p. 75-79)

Germany: Adelberger (2001); Börzel (2005, p. 245-257); Loughlin (2001, p.83-116); Committee of the Regions (2003); Council of Europe (1998, p. 83-98); Council of Europe (1999); Elazar (1991, p. 102-109); Filippov et al. (2004); Keating and Jones (1985, p. 173-190); Jones and Keating (1995, p. 189-213); Batley and Stoker (1991, p. 73-88); Harloff (1987, p. 40-46 and 62-65); Hesse (1991, p. 353-386); Hooghe and Marks (2001, p. 189-212); Griffiths (2002, p. 148-160); Hueglin and Fenna (2006); Humes and Martin (1969, p. 542-546); Humes (1991, p. 56-66); Jeffery (1997, p. 56-75); John (2001); OECD (1997, p. 213227); OECD (1999, p. 37-39); Chandler (1993, p. 99-117); Mény and Wright (1985, p. 104-124); TerMinassian (1997, p. 226-248); Swenden (2006); Engel and Van Ginderachter (1993, p. 60-65); Watts (1999)

Greece: Hesse (1991, p. 551-578); Committee of the Regions (2003); Council of Europe (2001); Jones and Keating (1995, p. 247-266); Getimis and Demetropoulou (2004); Harloff (1987, p. 66-71); Hooghe and Marks (2001, p. 189-212); Humes and Martin (1969, p. 547-550); John (2001); Loughlin, John (2001, p. 271-287); OECD (1997, p. 229-242); Engel and Jef Van Ginderachter (1993, p. 66-69)

Hungary: Friedrich Ebert Stiftung (2001, p. 37-74); Committee of the Regions (2003) ; Council of Europe (1998, p. 99-117); Council of Europe (2004); Dabla-Norris and Wade (2002); Fowle (2002); Bennet (1993, p. 208-224); Harloff (1987, p. 72-75); Högye (2001, p. 213-288); Keating and Hughes (2002, p. 80-81); Hughes et al. (2004, p. 30-60 and 120-128); Humes and Martin (1969, p. 551-554); Kimball (1998, p. 742); Marcou (2002, p. 29-63); Bennet (1993, p. 225-245); Ter-Minassian (1997, p. 660-679); OECD (1999, 
p. 40-41) ; OECD (2001); OECD (2002); Pálné Kovács et al. (2004); Soós et al. (2002, p. 15-106); Horváth (2000, p. 343-384)

Iceland: Council of Europe (1998); Council of Europe (2006); Harloff (1987, p. 76-79); Humes and Martin (1969, p. 555-556); OECD (1997, p. 243-255); OECD (1999, p. 42)

Ireland: Hesse (1991, p. 141-166); Batley and Stoker (1991, p. 155-169); Committee of the Regions (2003); Council of Europe (1999); Harloff and Martin (1987, p. 80-85); Keating and Jones (1985, p. 204-233); Jones and Michael Keating (1995, p. 231-246); Hooghe and Marks (2001, p. 189-212); Humes and Martin (1969, p. 557-562); John (2001); Loughlin, John (2001, p. 61-80); Chandler (1993, p. 28-52); OECD (1997, p. 255-278); Rees et al. (2004); Engel and Jef Van Ginderachter (1993, p. 80-82)

Italy: Sharpe (1993, p. 91-116); Ciaffi (2001); Committee of the Regions (2003); Council of Europe (2000); Mény and Wright (1985, p. 125-148); Hesse (1991, p. 517-550); Batley and Stoker (1991, p. 110-122); Jones and Keating (1995, p. 65-87); Jeffery (1997, p. 96-116); Ter-Minassian (1997, p. 249-284); Fabrini and Brunazzo (2003); Harloff (1987, p. 86-91); Hooghe and Marks (2001, p. 189-212); Humes and Martin (1969, p. 563-568.); John (2001); Loughlin (2001, p. 211-228); Keating and Jones (1985, p. 160172); OECD (1997, p. 279-290); OECD (2002); Putnam (1993); Page and Goldsmith (1987, p. 107-129); Chandler (1993, p. 73-98); Swenden (2006, p. 15-16); Engel and Van Ginderachter (1993, p. 83-88)

Japan: Council of Local Authorities for International Relations (2002); Elazar (1991, p. 134-137); Humes and Martin (1969, p. 450-454); Humes (1991, p. 66-76); Hesse (1991, p. 109-140); Ter-Minassian (1997, p. 285-323); OECD (1997, p. 291-304); OECD (1999, p. 43-45)

Latvia: Committee of the Regions (2003); Council of Europe (1999 and 2006); Dabla-Norris and Wade (2002); Elazar (1991, p. 263-281); Harloff (1987, p. 147-151); Hughes et al. (2004); Humes and Martin (1969, p. 628-632); Humes (1991, p. 81-93); OECD (2001); OECD (2002); Bennet (1993, p. 292-306); Horváth (2000, p. 115-164); Soós et al. (2002, p. 107-180)

Lithuania: Horváth (2000, p. 165-216); Committee of the Regions (2003); Council of Europe (1997 and 2006); Dabla-Norris and Wade (2002); Elazar (1991, p. 263-281); Harloff (1987, p. 147-151); Hughes et al. (2004, p. 30-60); Humes and Martin (1969, p. 628-632); Humes (1991, p. 81-93); OECD (2001); OECD (2002); Marcou (2002, p. 65-101); Bennet (1993, p. 292-306)

Luxembourg: Committee of the Regions (2003); Council of Europe (1997); Elazar (1991, p. 150-152); Harloff (1987, p. 92-95); Humes and Martin (1969, p. 559-572); Loughlin (2001, p. 163-181); OECD (1997, p. 305-314); Engel and Van Ginderachter (1993, p. 89)

Macedonia: Council of Europe (1999); Dabla-Norris and Wade (2002); Elazar (1991, p. 349-355); Harloff (1987, p. 161-166); Humes and Martin (1969, p. 633-637); UNDP (2005, p. 127-165); Friedrich Ebert Stiftung (2001, p. 172-193); Kandeva (2001, p. 241-288)

Malta: Council of Europe (1998 and 2006); Humes and Martin (1969, p. 573-575)

Netherlands: Batley and Stoker (1991, p. 123-133); Committee of the Regions (2003); Council of Europe (1999); Elazar (1991, p. 173-176); Harloff (1987, p. 96-102); Jones and Keating (1995, p. 214-230); Loughlin (2001, p. 143-172); Hooghe and Marks (2001, p. 189-212); Humes and Martin (1969, p. 576582); John (2001); OECD (1997, p. 333-349); OECD (1999, p. 49-51); OECD (2002); Engel and Van Ginderachter (1993, p. 90-92); Hesse (1991, p. 291-332); Sharpe (1993, p. 117-153)

New Zealand: Symons (1984, p. 126-132); Elazar (1991, p. 177-181); Humes and Martin (1969, p. 645-648); OECD (1997, p. 349-361); OECD (1999, p. 52-56)

Norway: Arter (2001); Council of Europe (1998); Page and Goldsmith (1987, p. 29-45); Hesse (1991, p. 211240); Sharpe (1993, p. 154-181); Harloff (1987, p. 103-107); Humes and Martin (1969, p. 583-587); John (2001) ; Batley and Stoker (1991, p. 198-229); OECD (1997, p. 363-374); OECD (1999, p. 57-60)

Poland: Keating and Hughes (2002, p. 121-145); Bialasiewicz (2002); Committee of the Regions (2003); Council of Europe (1998 and 2000); Czernielewska et al. (2004, p. 461-495); Dabla-Norris and Wade (2002); Ferry and Mcmaster (2005); Marcou (2002, p. 103-140); Harloff (1987, p. 108-112); Keating and Hughes (2002, p. 82-83); Hughes et al. (2004, p. 30-60 and 129-138); Humes and Martin (1969, p. 588593); Kimball (1998, p. 7-42); Horváth (2000, p. 216-254); Sharpe (1993, p. 182-209); OECD (1999, p. 6162) ; OECD (2001); OECD (2002); Soós et al. (2002, p. 181-204); Bennet (1993, p. 197-207)

Portugal: Committee of the Regions (2003); Council of Europe (1998a, p. 133-148, 1998b and 2006); Elazar (1991, p. 8-11); Harloff (1987, p. 113-119); Hooghe and Marks (2001, p. 189-212); Humes and Martin 
(1969, p. 594-599); John (2001); Loughlin, John (2001, p. 255-270); Nanetti et al. (2004); OECD (1997, p. 375-386); OECD (1999, p. 63-64); Hesse (1991, p. 497-516); Batley and Stoker (1991, p. 134-145); Jones and Keating (1995, p. 267-280); Engel and Van Ginderachter (1993, p. 93-96)

Romania: Keating and Hughes (2002, p. 161-181); Kandeva (2001, p. 351-416); Committee of the Regions (2003); Council of Europe (1999); Dabla-Norris and Wade (2002); Högye (2000, p. 289-248); Harloff (1987, p. 120-123); Keating and James Hughes (2002, p. 83-84); Hughes et al. (2004, p. 30-60); Humes and Martin (1969, p. 600-601); OECD (2002); Friedrich Ebert Stiftung (2001, p. 225-248); Soós et al. (2002, p. 285-369)

Russian Federation: Ter-Minassian (1997, p. 680-701); Council of Europe (2000); Dabla-Norris and Wade (2002); Elazar (1991, p. 263-281); Filippov et al. (2004); Harloff (1987, p. 147-151); Hughes (2001); Humes and Martin (1969, p. 628-632); Humes (1991, p. 81-93); Jackson and Lynn (2002); Munteanu and Popa (2001, p. 161-264); Bennet (1993, p. 278-291); Pinnick (2005); Söderlund (2005); Bennet (1993, p. 292306); Griffiths (2002, p. 249-269)

Serbia and Montenegro: Keating and Hughes (2002, p. 161-181); Griffiths (2002, p. 372-386); Dabla-Norris andWade (2002); Elazar (1991, p. 349-355); Harloff (1987, p. 161-166); Humes and Martin (1969, p. 633637); Friedrich Ebert Stiftung (2001, , p. 128-171); Kandeva (2001, p. 417-470); UNDP (2005, p. 166-194)

Slovak Republic: Bitušíková (2002); Keating and Hughes (2002, p. 85-105 and p. 147-160); Marcou (2002, p. 141-177); Committee of the Regions (2003); Council of Europe (1999) ; Bennet (1993, p. 259-277); Elazar (1991, p. 88-92); Harloff (1987, p. 31-34); Hughes et al. (2004, p. 30-60); Bennet (1993, p. 246-258); Horváth (2000, p. 297-342); OECD (2002); Soós (2006, p. 351-472)

Slovenia: Committee of the Regions (2003); Council of Europe (1998); Friedrich Ebert Stiftung (2001, p. 936); Elazar (1991, p. 349-355); Harloff (1987, p. 161-166); Keating and Hughes (2002, p. 86-87); Hughes et al. (2004, p. 30-60); Humes and Martin (1969, p. 633-637); OECD (2002); Horváth (2000, p. 385-421)

Spain: Agranoff (2004); Loughlin (2001, p. 229-253); Hesse (1991, p. 463-498); Page and Goldsmith (1987, p. 130-155); Committee of the Regions (2003); Council of Europe (1997); Council of Europe (1998, p. 149-172); Sharpe (1993, p. 210-246); Elazar (1991, p. 8-11 and p. 227-240); Filippov et al. (2004); Harloff (1987, p. 124-129); Griffiths (2002, p. 296-313); Hooghe and Marks (2001, p. 189-212); Hueglin and Fenna (2006); Humes and Martin (1969, p. 602-607); John (2001) ; Mény and Wright (1985, p. 236-272); Batley and Stoker (1991, p. 146-154); Jones and Keating (1995, p. 114-133); OECD (1997, p. 387-402); OECD (1999, p. 65-69) ; OECD (2002); Swenden (2006); Engel and Van Ginderachter (1993, p. 70-74); Watts (1999)

Sweden: Committee of the Regions (2003); Council of Europe (1997); Council of Europe (1998, p. 173-194); Batley and Stoker (1991, p. 170-189); Hesse (1991, p. 241-260); Hadenius (1999); Sharpe (1993, p. 315318); Harloff (1987, p. 130-135); Hooghe and Marks (2001, p. 189-212); Humes and Martin (1969, p. 608611); John (2001); Chandler (1993, p. 118-137); Page and Goldsmith (1987, p. 12-28); Loughlin (2001, p. 319-342); OECD (1997, p. 403-419); OECD (1999, p. 70-71) ; OECD (2002); Högye (2000, p. 401-428); Svensson and Östhol (2001)

Switzerland: Church and Dardanelli (2005); Council of Europe (1998a, p. 195-215, 1998b); Elazar (1991, p. 250-257); Filippov et al. (2004); Harloff (1987, p. 136-139); Hueglin and Fenna (20060; Humes and Martin (1969, p. 612-616); John (2001); Hesse (1991, p. 409-428); OECD (1997, p. 421-442); OECD (1999, p. 72-81); Ter-Minassian (1997, p. 324-341); Griffiths (2002, p. 314-328); Swenden (2006); Vatter (2005); Watts (1999)

Turkey: Committee of the Regions (2003); Council of Europe (1999); Harloff (1987, p. 140-146); Hesse (1991, p. 579-600); Humes and Martin (1969, p. 494-502); OECD (1997, p. 443-461)

United Kingdom: Agranoff (2004); Ayres and Pearce (2004); Mény and Wright (1985, p. 171-206); Casey (2002); Cole (2001); Committee of the Regions (2003); Council of Europe (1998, p. 217-237 and 2000) ; Bennet (1993, p. 80-94); Elazar (1991, p. 286-303); Goldsmith and Page (1987, p. 68-87); Keating and Jones (1985, p. 109-132); Harloff (1987, p. 152-160); Hooghe and Marks (2001, p. 189-212); Horgan (2004); Humes and Martin (1969, p. 617-627); Humes (1991, p. 104-120); Batley and Stoker (1991, p. 5872); Jeffery (1997, p. 131-144 and 2004); John (2001); Keating and Jones (1985, p. 89-108 and p. 133-159); Hesse (1991, p. 167-210); Keating and Jones (1985, p. 60-88); Jones and Keating (1995, p. 88-113); Chandler (1993, p. 7-27); Loughlin, John (2001, p. 37-60); McCall (2001); OECD (1997, p. 461-479); 
OECD (1999, p. 82) ; OECD (2002); Paterson (2002); Ter-Minassian (1997); Mény and Wright (1985, p. 33-78); Sharpe (1993, p. 247-295); Swenden (2006); Engel and Van Ginderachter (1993, p. 97-101);

Wilford et al. (2003)

United States: Chandler (1993, p. 138-158); Elazar (1991, p. 304-338); Fabrini and Sicurelli (2004, p. 232254); Filippov et al. (2004); Hesse (1991, p. 77-108); Hueglin and Alan (2006); Humes and Martin (1969, p. 356-364); Humes (1991, p. 121-131); OECD (1997, p. 481-498); Griffiths (2002, p. 342-357); TerMinassian (1997, p. 359-386); Watts (1999) 